Prepared in cooperation with the Bureau of Reclamation

\title{
Development of a Precipitation-Runoff Model to Simulate Unregulated Streamflow in the Salmon Creek Basin, Okanogan County, Washington
}

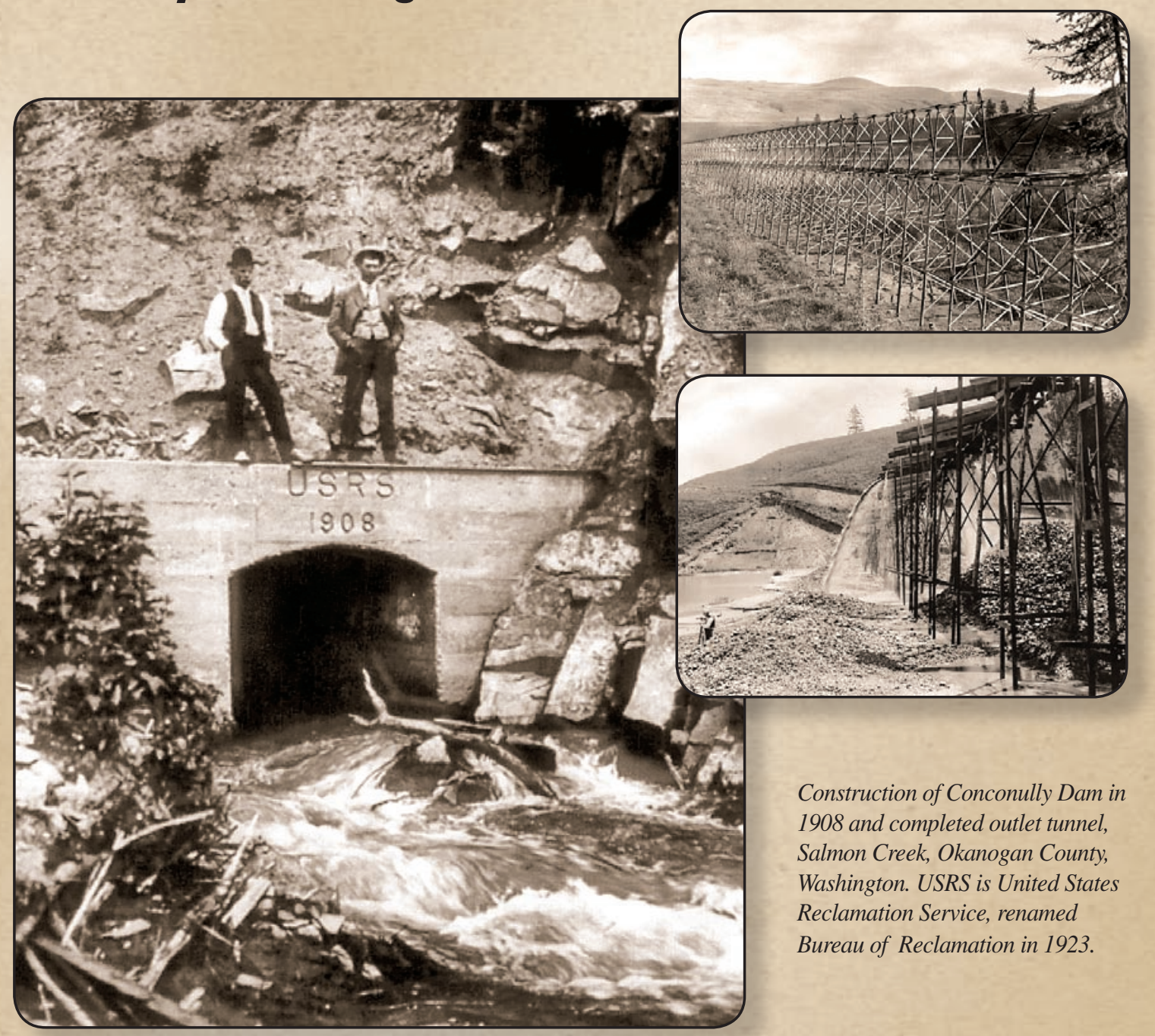

Scientific Investigations Report 2006-5274 
Cover: Photographs courtesy of the Bureau of Reclamation. 


\section{Development of a Precipitation-Runoff Model to Simulate Unregulated Streamflow in the Salmon Creek Basin, Okanogan County, Washington}

By Marijke van Heeswijk

Prepared in cooperation with the Bureau of Reclamation

Scientific Investigations Report 2006-5274 


\section{U.S. Department of the Interior DIRK KEMPTHORNE, Secretary}

\section{U.S. Geological Survey \\ Mark D. Myers, Director}

\section{U.S. Geological Survey, Reston, Virginia: 2006}

For product and ordering information:

World Wide Web: http://www.usgs.gov/pubprod

Telephone: 1-888-ASK-USGS

For more information on the USGS--the Federal source for science about the Earth, its natural and living resources, natural hazards, and the environment:

World Wide Web: http://www.usgs.gov

Telephone: 1-888-ASK-USGS

Any use of trade, product, or firm names is for descriptive purposes only and does not imply endorsement by the U.S. Government.

Although this report is in the public domain, permission must be secured from the individual copyright owners to reproduce any copyrighted materials contained within this report.

Suggested citation:

van Heeswijk, Marijke, 2006, Development of a precipitation-runoff model to simulate unregulated streamflow in the Salmon Creek Basin, Okanogan County, Washington: U.S. Geological Survey Scientific Investigations Report 2006-5274, $36 \mathrm{p}$. 


\section{Contents}

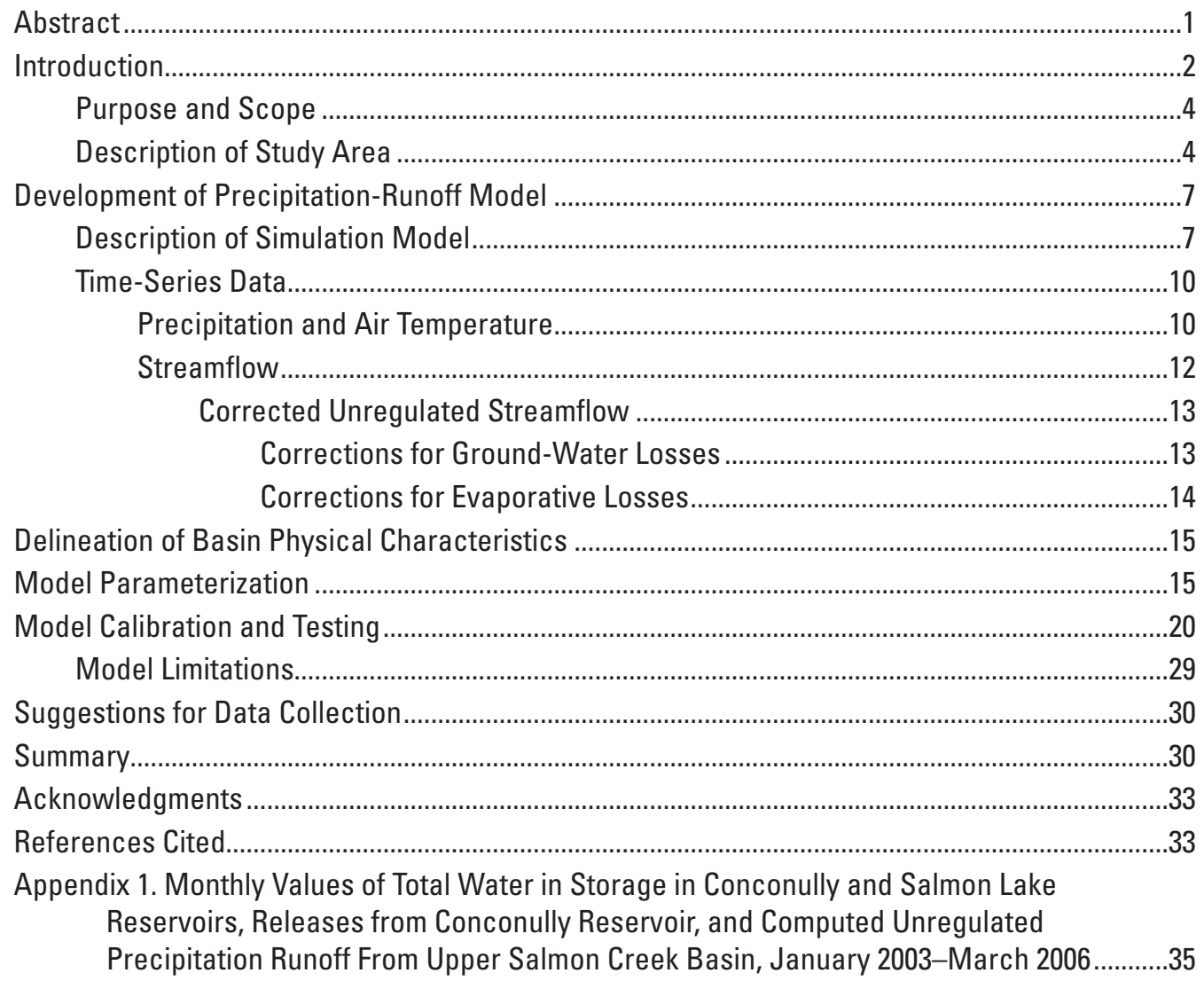




\section{Figures}

Figure 1. Map showing location of the Salmon Creek Basin study area and locations of climate stations, Okanogan County, Washington

Figure 2. Map showing locations of dams, diversions, and stream gages in the Salmon Creek Basin, Okanogan County, Washington

Figure 3. Map showing mean annual precipitation for the Salmon Creek Basin, Okanogan County, Washington, 1971-2000

Figure 4. Graphs showing mean monthly precipitation for the Salmon Creek Basin, Okanogan County, Washington, 1971-2000, and annual precipitation at Conconully, water years 1971-2000

Figure 5. Graph showing mean minimum and maximum air temperatures for the Conconully climate station, Okanogan County, Washington, 1971-2000

Figure 6. Diagram showing modified version of the Precipitation-Runoff Modeling System

Figure 7. Graph showing mean monthly reference evapotranspiration as a percentage of mean annual reference evapotranspiration for alfalfa (1982 Kimberly-Penman equation) at the Omak OMAW AgriMet station, water years 1990-2004

Figure 8. Map showing Modeling Response Units and drainage network delineated for the precipitation-runoff model for the Salmon Creek Basin, Okanogan County, Washington

Figure 9. Map showing generalized slopes in the Salmon Creek Basin, Okanogan County, Washington

Figure 10. Map showing land cover in the Salmon Creek Basin, Okanogan County, Washington

Figure 11. Map showing major subbasins and locations of model nodes in the Salmon Creek Basin, Okanogan County, Washington

Figure 12. Graphs showing estimated and simulated mean monthly unregulated streamflows for Salmon Creek at Conconully Dam, Okanogan County, Washington

Figure 13. Graphs showing time series of estimated and simulated monthly mean unregulated streamflows for Salmon Creek at Conconully Dam, Okanogan County, Washington

Figure 14. Graph showing time series of estimated and simulated annual mean unregulated streamflows for Salmon Creek at Conconully Dam, Okanogan County, Washington.

Figure 15. Graphs showing measured and simulated mean monthly snowpack water-equivalent for the Salmon Meadows SNOTEL station, Okanogan County, Washington

Figure 16. Graphs showing time series of measured and simulated monthly mean snowpack water-equivalent for the Salmon Meadows SNOTEL station, Okanogan County, Washington 


\section{Tables}

Table 1. Modules used in the precipitation-runoff model $\ldots \ldots \ldots \ldots \ldots \ldots \ldots \ldots \ldots \ldots \ldots$

Table 2. Climate stations used in model simulations or to estimate missing data ........... 11

Table 3. Estimated evaporation from Conconully Reservoir, assuming a mean annual free-water-surface evaporation of 30 inches

Table 4. Periods of simulation and model input time series for each type of model simulation

Table 5. Mean monthly, annual, and April-July estimated and simulated unregulated streamflows for Salmon Creek at Conconully Dam and the percentage of error for the CALIBRATION, TESTING 1, TESTING 2, TESTING 3, TESTING 4, and COMPOSITE model simulations

Table 6. Annual mean and April-July mean estimated and unregulated streamflows for Salmon Creek at Conconully Dam for the driest 4 water years and wettest 4 water years, 1950-89, and the percentage of error and the absolute error for the model simulations

\section{Conversion Factors, Datums, and Abbreviations or Acronyms}

Conversion Factors

\begin{tabular}{lcl}
\hline \multicolumn{1}{c}{ Multiply } & By & \multicolumn{1}{c}{ To obtain } \\
\hline acre & 4,047 & square meter \\
acre & 0.004047 & square kilometer \\
acre-foot (acre-ft) & 1,233 & cubic meter \\
acre-foot per month (acre-ft/mo) & 1,233 & cubic meter per month \\
acre-foot per year (acre-ft/yr) & 1,233 & cubic meter per year \\
cubic foot $\left(\mathrm{ft}^{3}\right)$ & 0.02832 & cubic meter \\
cubic foot per second $\left(\mathrm{ft}^{3} / \mathrm{s}\right)$ & 0.02832 & cubic meter per second \\
cubic foot per day $\left(\mathrm{ft}^{3} / \mathrm{d}\right)$ & 0.02832 & cubic meter per day \\
foot $(\mathrm{ft})$ & 0.3048 & meter \\
foot per day $(\mathrm{ft} / \mathrm{d})$ & 0.3048 & meter per day \\
inch (in.) & 25.4 & millimeter \\
inch per year (in/yr) & 25.4 & millimeter per year \\
mile $(\mathrm{mi})$ & 1.609 & kilometer \\
square foot $\left(\mathrm{ft}^{2}\right)$ & 0.09290 & square meter \\
square mile $\left(\mathrm{mi}^{2}\right)$ & 2.590 & square kilometer \\
\hline
\end{tabular}

Temperature in degrees Fahrenheit $\left({ }^{\circ} \mathrm{F}\right)$ may be converted to degrees Celsius $\left({ }^{\circ} \mathrm{C}\right)$ as follows:

$$
{ }^{\circ} \mathrm{C}=\left({ }^{\circ} \mathrm{F}-32\right) / 1.8
$$

\section{Datums}

Vertical coordinate information is referenced to the North American Vertical Datum of 1988 (NAVD 88).

Horizontal coordinate information is referenced to the North American Datum of 1983 (NAD 83).

Altitude, as used in this report, refers to distance above the vertical datum. 


\section{Conversion Factors, Datums, and Abbreviations or Acronyms-Continued}

Abbreviations or Acronyms

\begin{tabular}{ll}
\hline \multicolumn{1}{c}{ Abbreviation or Acronym } & \multicolumn{1}{c}{ Meaning } \\
\hline CUS & corrected unregulated streamflow \\
DEM & digital elevation model \\
DOE & Washington State Department of Ecology \\
DSS & Decision Support System \\
ESP & Extended Streamflow Prediction \\
HDB & Hydrologic Database \\
MMS & Modular Modeling System \\
MRU & Modeling Response Unit \\
NRCS & Natural Resources Conservation Service \\
NWS & National Weather Service \\
OID & Okanogan Irrigation District \\
OUI & Object User Interface \\
PRMS & Precipitation-Runoff Modeling System \\
Reclamation & Bureau of Reclamation \\
USGS & U.S. Geological Survey \\
UUS & uncorrected unregulated streamflow \\
WARSMP & Watershed and River Systems Management Program \\
\hline
\end{tabular}




\title{
Development of a Precipitation-Runoff Model to Simulate Unregulated Streamflow in the Salmon Creek Basin, Okanogan County, Washington
}

\author{
By Marijke van Heeswijk
}

\section{Abstract}

Surface water has been diverted from the Salmon Creek Basin for irrigation purposes since the early 1900s, when the Bureau of Reclamation built the Okanogan Project. Spring snowmelt runoff is stored in two reservoirs, Conconully Reservoir and Salmon Lake Reservoir, and gradually released during the growing season. As a result of the out-of-basin streamflow diversions, the lower 4.3 miles of Salmon Creek typically has been a dry creek bed for almost 100 years, except during the spring snowmelt season during years of high runoff. To continue meeting the water needs of irrigators but also leave water in lower Salmon Creek for fish passage and to help restore the natural ecosystem, changes are being considered in how the Okanogan Project is operated.

This report documents development of a precipitationrunoff model for the Salmon Creek Basin that can be used to simulate daily unregulated streamflows. The precipitationrunoff model is a component of a Decision Support System (DSS) that includes a water-operations model the Bureau of Reclamation plans to develop to study the water resources of the Salmon Creek Basin. The DSS will be similar to the DSS that the Bureau of Reclamation and the U.S. Geological Survey developed previously for the Yakima River Basin in central southern Washington.

The precipitation-runoff model was calibrated for water years 1950-89 and tested for water years 1990-96. The model was used to simulate daily streamflows that were aggregated on a monthly basis and calibrated against historical monthly streamflows for Salmon Creek at Conconully Dam. Additional calibration data were provided by the snowpack waterequivalent record for a SNOTEL station in the basin. Model input time series of daily precipitation and minimum and maximum air temperatures were based on data from climate stations in the study area. Historical records of unregulated streamflow for Salmon Creek at Conconully Dam do not exist for water years 1950-96. Instead, estimates of historical monthly mean unregulated streamflow based on reservoir outflows and storage changes were used as a surrogate for the missing data and to calibrate and test the model. The estimated unregulated streamflows were corrected for evaporative losses from Conconully Reservoir (about $1 \mathrm{ft}^{3} / \mathrm{s}$ ) and groundwater losses from the basin (about $\left.2 \mathrm{ft}^{3} / \mathrm{s}\right)$. The total of the corrections was about 9 percent of the mean uncorrected streamflow of $32.2 \mathrm{ft}^{3} / \mathrm{s}(23,300$ acre-ft/yr) for water years 1949-96. For the calibration period, the basinwide mean annual evapotranspiration was simulated to be 19.1 inches, or about 83 percent of the mean annual precipitation of 23.1 inches.

Model calibration and testing indicated that the daily streamflows simulated using the precipitation-runoff model should be used only to analyze historical and forecasted annual mean and April-July mean streamflows for Salmon Creek at Conconully Dam. Because of the paucity of model input data and uncertainty in the estimated unregulated streamflows, the model is not adequately calibrated and tested to estimate monthly mean streamflows for individual months, such as during low-flow periods, or for shorter periods such as during peak flows. No data were available to test the accuracy of simulated streamflows for lower Salmon Creek. As a result, simulated streamflows for lower Salmon Creek should be used with caution.

For the calibration period (water years 1950-89), both the simulated mean annual streamflow and the simulated mean April-July streamflow compared well with the estimated uncorrected unregulated streamflow (UUS) and corrected unregulated streamflow (CUS). The simulated mean annual streamflow exceeded UUS by 5.9 percent and was less than CUS by 2.7 percent. Similarly, the simulated mean April-July streamflow exceeded UUS by 1.8 percent and was less than CUS by 3.1 percent. However, streamflow was significantly undersimulated during the low-flow, baseflow-dominated months of November through February when simulated monthly streamflows were as much as 57.2 percent less than UUS and significantly oversimulated during August and September when simulated monthly streamflows were as much as 193.6 percent more than CUS. Only a small percentage of the estimated mean annual streamflow occurs during baseflow-dominated months. About 84 percent of the estimated mean annual UUS occurs from April through July. For the testing period (water years 1990-96), the model simulated a close fit for the mean annual streamflow and a 
good fit for the mean April-July streamflow. The simulated mean annual streamflow exceeded UUS by 10.7 percent and was the same as CUS. The simulated mean April-July streamflow exceeded UUS by 5.1 percent and was less than CUS by 0.8 percent. Testing of the precipitation-runoff model using different model input time series demonstrated that the model simulates the best fit between estimated and simulated streamflows for Salmon Creek at Conconully Dam, if the input time series were based on daily minimum and maximum air temperatures for the Omak OMAW AgriMet station and daily precipitation and minimum and maximum air temperatures for the Conconully climate station or the Conconully CCR Hydromet station.

The precipitation-runoff model could be improved if additional data were collected. Specifically, it is suggested that year-round collection of climate data be resumed at
Conconully climate station and that a stream gage be installed in Salmon Creek downstream of the spillway of Conconully Dam to measure all runoff from the upper Salmon Creek Basin.

\section{Introduction}

Salmon Creek, a tributary to the Okanogan River (fig. 1), contains two reservoirs that supply irrigation water for out-ofbasin use. The irrigation project, called the Okanogan Project, was authorized by the U.S. Department of the Interior in 1905 and has been in operation since the early 1900s. Conconully Reservoir is formed by Conconully Dam (fig. 2), which was completed in 1910, and Salmon Lake Reservoir (also referred to as Conconully Lake in other publications) is formed by

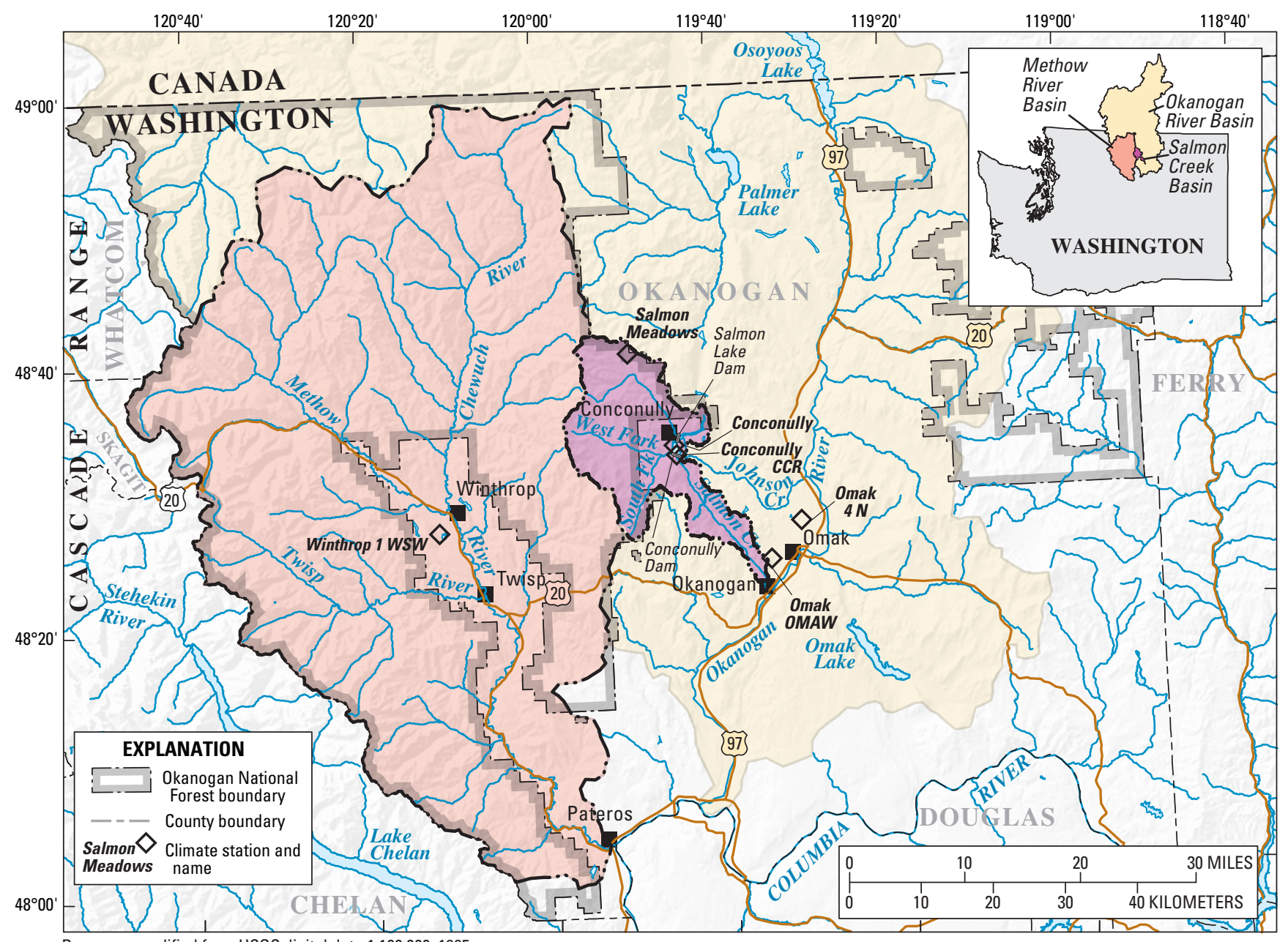

Base map modified from USGS digital data 1:100,000, 1995

Hillshade modified from National Elevation Dataset, 2000, 10-meter resolution

Universal Transverse Mercator projection, zone 11,

North American Datum of 1983, North American Vertical Datum of 1988

Figure 1. Location of the Salmon Creek Basin study area and locations of climate stations, Okanogan County, Washington. 


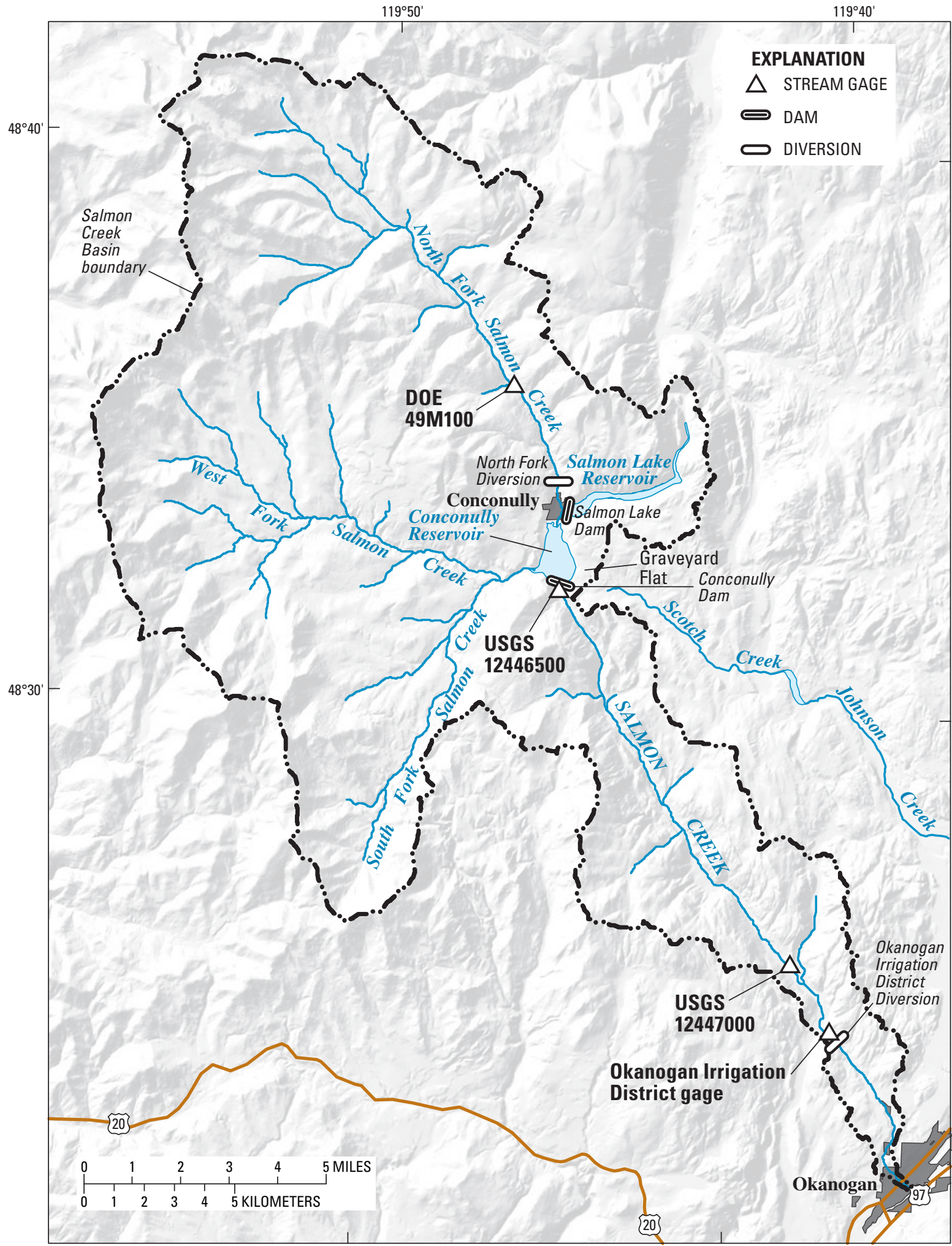

Base map modified from USGS digital data 1:100,000, 1995

Hillshade modified from National Elevation Dataset, 2000, 10-meter resolution

Universal Transverse Mercator projection, zone 11,

North American Datum of 1983, North American Vertical Datum of 1988

Figure 2. Locations of dams, diversions, and stream gages in the Salmon Creek Basin, Okanogan County, Washington. 
Salmon Lake Dam, which was completed in 1921. The Bureau of Reclamation (Reclamation) owns the dams and the project is operated by the Okanogan Irrigation District (OID). As a result of streamflow diversions, the lower 4.3 miles of Salmon Creek typically is a dry creek bed except during the spring snowmelt season during years of high runoff (Dames and Moore, 1999). To continue meeting the water needs of irrigators but also to leave water in lower Salmon Creek for fish passage and to help restore the natural ecosystem, changes in how the Okanogan Project is operated currently (2006) are being considered. In preparation for the potential changes, a draft environmental impact statement that considers different management alternatives was issued in August 2004 (U.S. Department of Energy, 2004).

Reclamation plans to develop a water-operations model to study the water resources of the Salmon Creek Basin and asked the U.S. Geological Survey (USGS) to develop a precipitation-runoff model that will provide input data for the water-operations model. Both models are components of a Decision Support System (DSS) for the Salmon Creek Basin that will be similar to the DSS that Reclamation and the USGS developed previously for the Yakima River Basin in central southern Washington (Mastin and Vaccaro, 2002b; U.S. Geological Survey, 1998). In addition to the two models, the DSS consists of a Hydrologic Database (HDB) that is an interface between the models. The HDB provides daily time-series input to the precipitation-runoff model (described in this report) and receives daily streamflows simulated by the model. The streamflows then are provided as input to the planned RiverWare model (Bureau of Reclamation and CADSWES, 2000), a water-operations planning model that will be used to simulate different water-operations options for the available streamflow. The DSS for the Yakima River Basin was developed as part of the Watershed and River Systems Management Program (WARSMP), a federallyfunded program under which Reclamation and the USGS have collaborated since 1995 (U.S. Geological Survey and Bureau of Reclamation, 2006). WARSMP's purpose is to develop, test, and implement a framework for water-resources management in Reclamation Act states.

The objective of this study was to develop the precipitation-runoff-model component of the DSS. The precipitation-runoff-model component can be used to simulate historical daily unregulated streamflows for different locations in the Salmon Creek Basin and to forecast daily unregulated streamflows for the runoff season (April-July) or longer periods as far as 1 year in the future. Forecasting is based on near-real-time hydrologic conditions in the basin and an assumption that historical climate records will recur with the same probability in the future as in the past. Reclamation plans to use the simulated historical daily unregulated streamflows for long-term-planning studies and may use forecasted daily streamflows to assist with seasonal planning of water operations.

\section{Purpose and Scope}

This report documents development of a precipitationrunoff model for the Salmon Creek Basin in Okanogan County, Washington, that can be used to simulate daily unregulated streamflows in the basin. Unregulated streamflows are defined as streamflows unaltered by human activities such as streamflow diversions and impoundments in reservoirs. The precipitation-runoff model that was developed is a modified version of the Precipitation-Runoff Modeling System (PRMS; Leavesley and others, 1983) and was run within the Modular Modeling System (MMS; Leavesley and others, 1996). The modified model version that was used is identical to that used previously to simulate streamflow in the neighboring Methow River Basin (Ely, 2003; Ely and Risley, 2001). Input data used to run the model are based on daily precipitation and daily minimum and maximum air temperatures for three National Weather Service stations (Conconully, Omak 4 N, and Winthrop 1 WSW), a Natural Resources Conservation Service SNOTEL station (Salmon Meadows), a Bureau of Reclamation AgriMet station (Omak OMAW), and a Bureau of Reclamation Hydromet station (Conconully CCR). The model was used to simulate daily streamflows that were aggregated on a monthly basis and calibrated against historical monthly streamflows for Salmon Creek at Conconully Dam. Historical monthly streamflows were estimated by Dames and Moore (1999) and the U.S. Department of Energy (2004) and as part of this study from monthly outflows from Conconully Reservoir and from storage changes in Conconully Reservoir and Salmon Lake Reservoir. Additional calibration data were provided by the snowpack water-equivalent record for the Salmon Meadows SNOTEL station. The precipitation-runoff model was calibrated for water years 1950-89 (a water year starts October 1 and ends September 30) and tested for water years 1990-96.

\section{Description of Study Area}

The Salmon Creek Basin is located in the northeastern part of the Cascade Range (fig. 1) and encompasses an area of $152 \mathrm{mi}^{2}$. Elevations in the basin range from 820 to $8,250 \mathrm{ft}$ and have a mean of 4,050 ft. Upper Salmon Creek Basin, defined 
as the area upstream of Conconully Dam, encompasses 78 percent of the basin. Elevations in the upper basin range from 2,270 to $8,250 \mathrm{ft}$ and have a mean of 4,450 ft. Much of the upper basin is located in the Okanogan National Forest and is largely vegetated with evergreen forests of Ponderosa pine (Pinus ponderosa) and Interior Douglas-fir (Pseudotsuga menziesii) (Cassidy, 1997). The study area is sparsely populated. Conconully, the only town in the basin, had a population of 185 in 2000 (U.S. Census Bureau, 2006).

The two reservoirs in the basin, Conconully Reservoir and Salmon Lake Reservoir (fig. 2), have a maximum active storage capacity of about 13,000 and 10,500 acre-ft, respectively (U.S. Department of Energy, 2004). (Active storage capacity is defined as the usable reservoir capacity available for seasonal or cyclic water storage.) Most of the water stored in the reservoirs is spring snowmelt runoff that is released later in the season or in subsequent years for irrigation purposes. The Okanogan Project currently supplies irrigation water to about 5,000 acres of agricultural land outside Salmon Creek Basin along the Okanogan River near the town of Okanogan (Bureau of Reclamation, 2006b).

Salmon Lake Dam allows the level of the natural Salmon Lake to be raised. Water in the reservoir behind the dam consists of runoff from the Salmon Lake subbasin and water that is diverted from North Fork Salmon Creek at the North Fork diversion (fig. 2). Releases from Salmon Lake Reservoir flow into Conconully Reservoir, which also receives runoff from West Fork Salmon Creek and any runoff from North Fork Salmon Creek that is not diverted to Salmon Lake Reservoir. South Fork Salmon Creek joins West Fork Salmon Creek about $0.6 \mathrm{mi}$ west of Conconully Reservoir. Seepage, releases, and uncontrolled spills from Conconully Reservoir flow about $12 \mathrm{mi}$ downstream along the main stem of Salmon Creek to the OID diversion (fig. 2) from where water is diverted outside the basin through a series of canals. Any water not diverted flows another $4.3 \mathrm{mi}$ and then discharges to the Okanogan River. Since the early days of the Okanogan Project, the streambed between the OID diversion and the mouth of Salmon Creek has been dry except during those spring-runoff events when uncontrolled spills occurred at Conconully Dam (Dames and Moore, 1999).

Mean annual precipitation in the Salmon Creek Basin based on PRISM data from the Spatial Climate Analysis Service-Oregon State University (2006) during the most recent climate-normal period (1971-2000) was about 21 in. and ranged from about $12 \mathrm{in}$. near the mouth of the basin to almost 33 in. near the crest (fig. 3). In the upper basin, mean annual precipitation was about 23 in. and ranged from 15.4 in. to almost 33 in. (Spatial Climate Analysis Service-Oregon State University, 2006). About 58 percent of mean annual precipitation occurs from October through March. Minimum precipitation in the basin occurs in September, and maximum precipitation occurs in November (fig. 4A). A secondary precipitation maximum occurs in May. The snowpack that accumulates in the basin during the winter melts off by early summer. The interannual variability in precipitation in the basin is large. For example, based on the National Weather Service climate record for the Conconully station, for which some missing data were estimated in this study, the mean annual precipitation for 1971-2000 was about 15 in. The minimum was $7.8 \mathrm{in}$. in water year 1979, and the maximum was 26.3 in. in water year 1983 (fig. 4B). The mean minimum air temperature for the Conconully station ranged from about 15 to $53^{\circ} \mathrm{F}$, and the mean maximum ranged from about 31 to $82^{\circ} \mathrm{F}$ (fig. 5). On average, the coldest month of the year is January and the warmest month is August.

The large amount of interannual variability in precipitation in the basin results in a large amount of interannual variability in runoff. For example, based on information provided by Dames and Moore (1999), the U.S. Department of Energy (2004), and T. Sullivan (Okanogan Irrigation District, written commun., 2006), the mean annual runoff from upper Salmon Creek Basin for water years 1949-2004 is estimated to be about 23,300 acre-ft (about $\left.32 \mathrm{ft}^{3} / \mathrm{s}\right)$. The minimum annual mean was 4,400 acre- $\mathrm{ft}\left(6 \mathrm{ft}^{3} / \mathrm{s}\right)$ in water year 1966, and the maximum annual mean was 65,800 acre-ft $\left(91 \mathrm{ft}^{3} / \mathrm{s}\right)$ in water year 1983 . The mean annual runoff from upper Salmon Creek Basin is about equal to the total maximum active storage capacity of Conconully and Salmon Lake Reservoirs. During most years, the majority of annual runoff from the upper basin occurs from April through July because of melting of the snowpack that accumulated during the previous autumn and winter.

Most of the Salmon Creek Basin is in steep terrain that consists predominantly of Mesozoic intrusive and metamorphic rocks and Mesozoic-Paleozoic metamorphic rocks (Schuster, 2005). In parts of the lower basin and near the center, including the areas surrounding Conconully and Conconully Reservoir, sedimentary deposits of Pleistocene continental glacial drift comprise the surface. Most of lower Salmon Creek runs along the trace of a fault (Schuster, 2005) that has formed a narrow valley. Based on the topography and surficial geology of the area, at some time in the geologic past, lower Salmon Creek may have drained to the southeast of Conconully Reservoir into what are now Scotch and Johnson Creeks instead of into the present channel (fig. 2). 


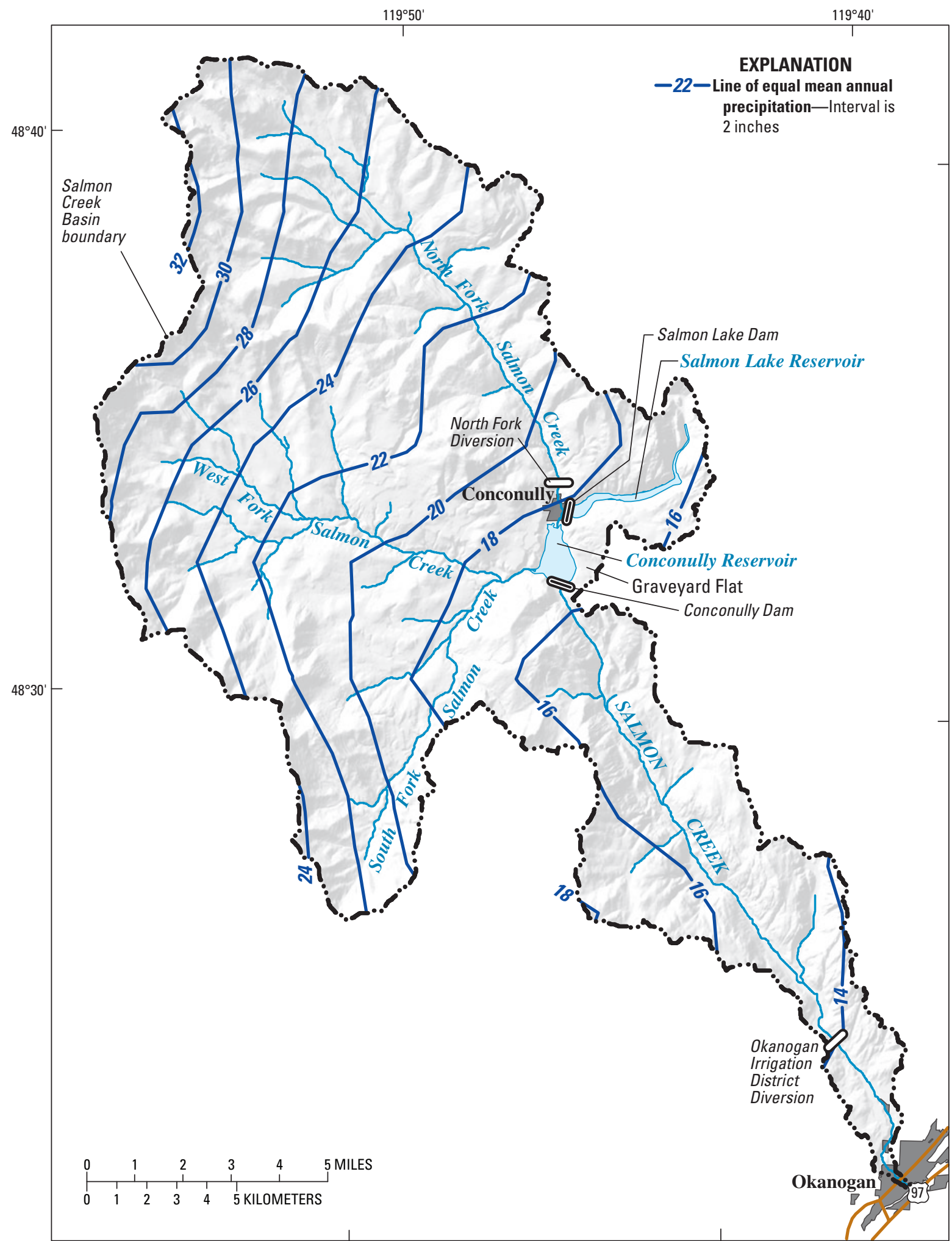

Base map modified from USGS digital data 1:100,000, 1995

Hillshade modified from National Elevation Dataset, 2000, 10-meter resolution

Universal Transverse Mercator projection, zone 11,

North American Datum of 1983, North American Vertical Datum of 1988

Figure 3. Mean annual precipitation for the Salmon Creek Basin, Okanogan County, Washington, 1971-2000.

(Based on PRISM data from the Spatial Climate Analysis Service-Oregon State University, 2006.) 

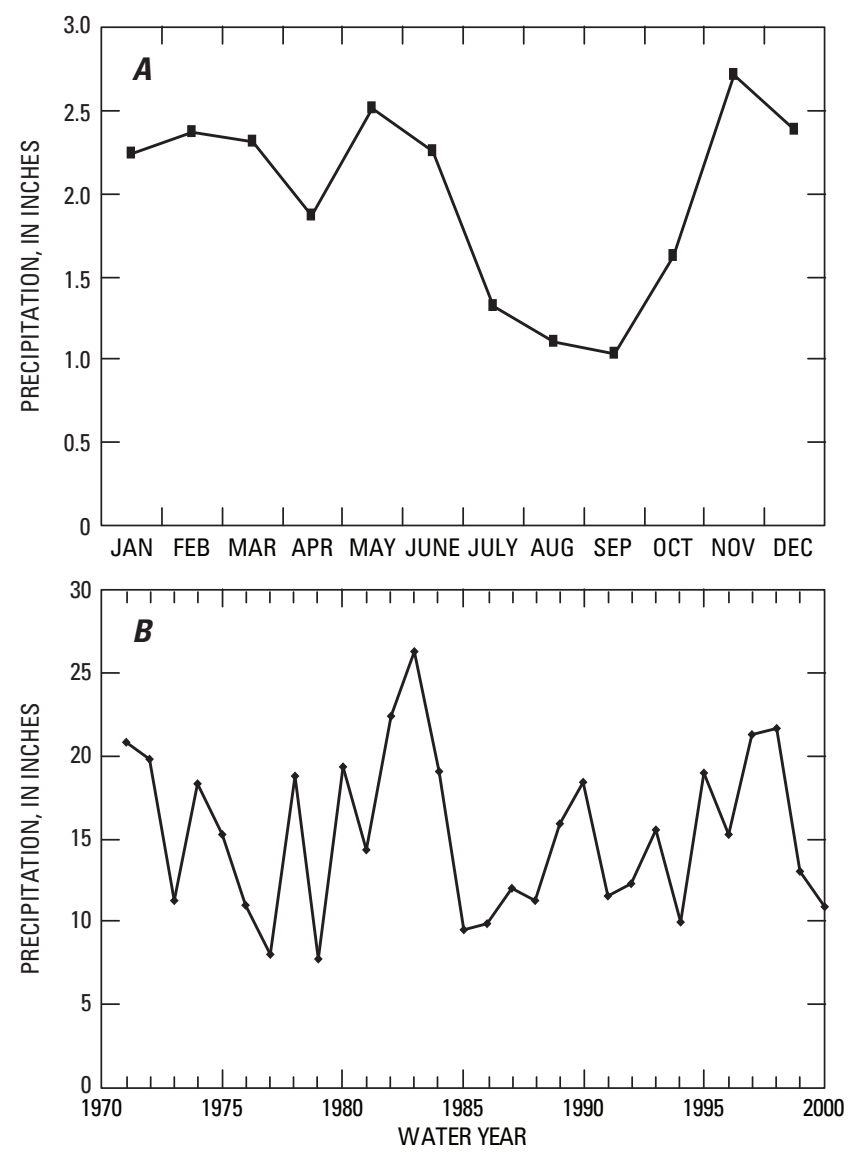

Figure 4. Mean monthly precipitation for the Salmon Creek Basin, Okanogan County, Washington, 1971-2000 (based on PRISM data from the Spatial Climate Analysis Service-Oregon State University, 2006), and annual precipitation at Conconully, water years 1971-2000.

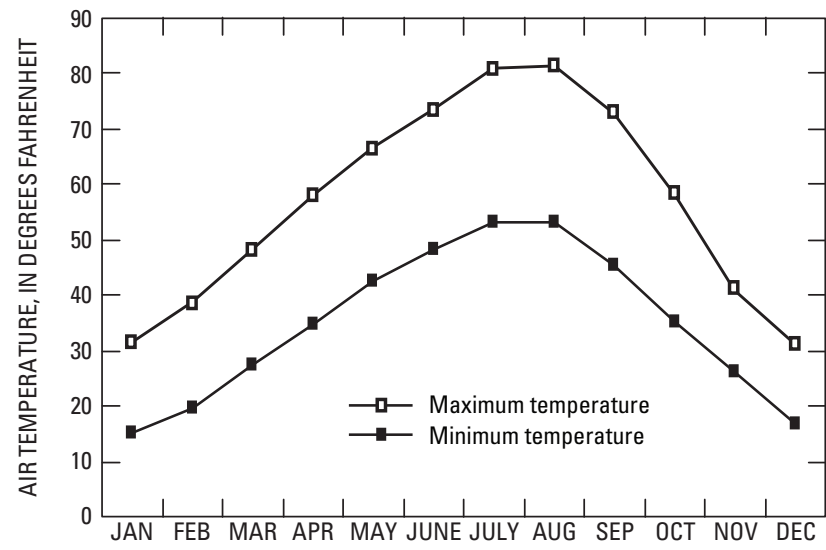

Figure 5. Mean minimum and maximum air temperatures for the Conconully climate station, Okanogan County, Washington, 1971-2000.

\section{Development of Precipitation-Runoff Model}

A modified version of the distributed-parameter, physically-based PRMS (Leavesley and others, 1983) was used to numerically simulate the hydrologic processes that occur in the Salmon Creek Basin. The model was run inside the MMS (Leavesley and others, 1996), which is a modeling system that allows users to develop application-specific models by selecting or creating a set of modules that each represent specific hydrologic processes. Examples of such processes include interception of precipitation by vegetation, evapotranspiration, and snow accumulation and melt.

In addition to the Salmon Creek Basin, MMS and/ or PRMS have been used for many other basins in the western United States, including the Yakima River Basin in Washington (Mastin and Vaccaro, 2002b), small basins in the Oregon Coast Range (Risley, 1994), the Willamette River Basin in Oregon (Laenen and Risley, 1997), the San Juan River Basin in Colorado and New Mexico (Kuhn and others, 1998), the Truckee River Basin in California and Nevada (Jeton, 1999), and the upper Rio Grande Basin in Colorado and New Mexico (Boyle and others, 2004).

\section{Description of Simulation Model}

The modified version of the PRMS (Leavesley and others, 1983) used in this study simulates hydrologic processes that occur in Salmon Creek Basin (fig. 6). The model was developed from a set of 15 modules given in table 1 that are identical to those used in precipitation-runoff simulations for the neighboring Methow River Basin (Ely and Risley, 2001; Ely, 2003). Each module represents either a hydrologic process or reads model input parameters or time series. Of the 15 modules, 5 are standard PRMS modules (Leavesley and others, 1983 and 1996) and 10 are modified versions developed for either the Yakima River Basin study (Mastin and Vaccaro, 2002a and 2002b) or the Methow River Basin study (Ely and Risley, 2001; Ely, 2003). The functionality of the module that reads model input time series of irrigation diversions, irrigation returns, and irrigation applications (divrt_apply_prms.f, table 1) is not used in this study because the precipitation-runoff model is used to simulate unregulated streamflow. A detailed description of the combination of modules used in this study is provided in the documentation of the precipitation-runoff simulations for the Methow River Basin (Ely and Risley, 2001).

The Methow River Basin model was selected so that calibrated parameters from that model could be used as initial estimates for model parameters in this study. Justifications for this approach are that the Methow River and Salmon Creek Basins are adjacent and share some hydrologic characteristics and that multiple long-term records of measured daily streamflows for the Methow River Basin were available for 


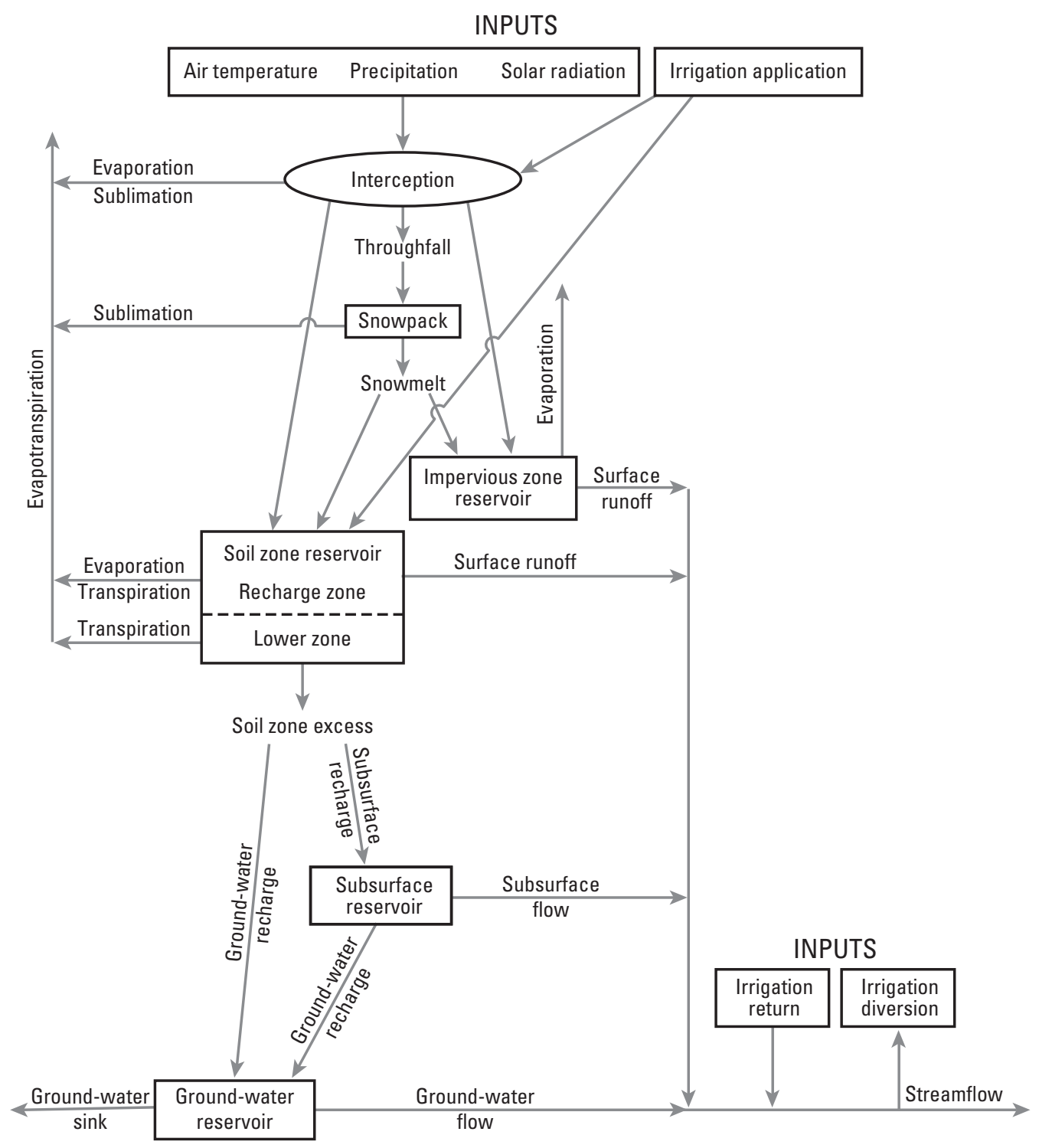

Figure 6. Modified version of the Precipitation-Runoff Modeling System.

model calibration while none are available for the Salmon Creek Basin. Both the Methow River and Salmon Creek Basins drain mountainous subbasins on the east side of the Cascade Range (fig. 1) that have similar types of vegetation. The elevations in the basins also are similar and range from $775-8,950 \mathrm{ft}$ in the Methow River Basin and from $820-8,250 \mathrm{ft}$ in the Salmon Creek Basin. Some differences between the basins are that the area of the Methow River Basin is significantly greater than that for the Salmon Creek Basin $\left(1,800 \mathrm{mi}^{2}\right.$ versus $\left.152 \mathrm{mi}^{2}\right)$ and that mean annual precipitation for the Methow River Basin is greater than that for the Salmon Creek Basin (32 in. versus 21 in.).

Spatial diversity in the model area is represented by simulating the basin as a set of sub-areas, called Modeling Response Units (MRUs), that have similar hydrologic characteristics. Characteristics assigned to each MRU included such parameters as slope and aspect, elevation, vegetation type and summer and winter density, soil type, and percent pervious. In addition to the spatial characteristics, model inputs included time series of measured or estimated precipitation and air temperatures. The model distributes the data from the locations of the climate stations to each MRU by considering differences in elevations and distances between the MRUs and the stations.

At each MRU, the model simulates a sequence of hydrologic processes (fig. 6) at a user-selected time step, which was 24 hours for this study. At the end of each time step, several model outputs, including surface runoff, subsurface flow, and ground-water flow, are available at each MRU. Those model outputs form the components of streamflow for unregulated conditions, when irrigation diversions and returns do not occur (fig. 6). The time series 
Table 1. Modules used in the precipitation-runoff model.

[MRU, Modeling Response Unit; PRMS, Precipitation-Runoff Modeling System; YRBS, Yakima River Basin study (Mastin and Vaccaro, 2002a and 2002b); MRBS, Methow River Basin study (Ely and Risley, 2001; Ely, 2003)]

\begin{tabular}{|c|c|c|}
\hline Name of module used & Module function & Version description \\
\hline basin_prms.f & Declares basin and MRU physical parameters. & Standard PRMS \\
\hline soltab_prms.f & Computes potential solar radiation. & Standard PRMS \\
\hline obs_sno.f & Reads measured data. & YRBS \\
\hline divrt_apply_prms. $\mathrm{f}^{1}$ & $\begin{array}{l}\text { Reads daily values of diversions, returns, and irrigation } \\
\text { applications. }\end{array}$ & YRBS \\
\hline temp_2sta_prms_dist2.f & Distributes temperatures to MRUs. & YRBS \\
\hline precip_prms_dist2.f & $\begin{array}{l}\text { Determines precipitation type and distributes precipitation } \\
\text { to MRUs. }\end{array}$ & YRBS \\
\hline ccsolrad_prms.f & $\begin{array}{l}\text { Computes daily solar radiation from temperature/cloud- } \\
\text { cover relation. }\end{array}$ & Standard PRMS \\
\hline potet_jh_prms.f & $\begin{array}{l}\text { Determines whether transpiration is occurring and computes } \\
\text { potential evapotranspiration using the Jensen-Haise (1963) } \\
\text { approach. }\end{array}$ & Standard PRMS \\
\hline intcp_prms_apply.f & $\begin{array}{l}\text { Computes amount of intercepted precipitation and evaporation } \\
\text { from interception. }\end{array}$ & YRBS \\
\hline snowcomp_prms_gmelt.f & $\begin{array}{l}\text { Computes snowpack accumulation and depletion using an } \\
\text { energy-budget approach. }\end{array}$ & YRBS \\
\hline srunoff_smidx_prms_glacr_apply.f & Computes surface runoff and infiltration. & YRBS \\
\hline smbal_prms_wtrgmelt.f & $\begin{array}{l}\text { Computes soil-moisture mass balance. Computes infiltration, } \\
\text { actual evapotranspiration, and seepage to subsurface and } \\
\text { ground-water reservoirs. }\end{array}$ & YRBS \\
\hline ssflow_prms.f & $\begin{array}{l}\text { Computes sum of inflows to subsurface reservoirs and calculates } \\
\text { outflow to ground-water reservoirs and streams. }\end{array}$ & Standard PRMS \\
\hline gwflow_loss_min_darcy.f & $\begin{array}{l}\text { Computes sum of inflows to ground-water reservoirs and outflow } \\
\text { to streams and ground-water sinks. }\end{array}$ & MRBS \\
\hline musroute_prms_divretrn.f & Routes water between stream nodes. & YRBS \\
\hline
\end{tabular}

${ }^{1}$ Functionality not used in this study.

of simulated streamflow components for each MRU are assigned to user-selected stream nodes that represent different locations of interest in the stream network. At each node, the contributions from the assigned MRUs are accumulated and routed downstream to simulate the daily streamflow at the various stream locations represented by the nodes. Simulated streamflows are compared to estimated streamflows and the model is calibrated by adjusting the model parameters until the fit between the simulated and estimated values is reasonable. For this study, measurements of daily streamflows were not available. Therefore, the model was calibrated by comparing simulated and estimated monthly mean streamflows.

After calibration, the precipitation-runoff model can be used to forecast daily unregulated streamflows based on near-real-time known or simulated initial hydrologic conditions in the basin and an assumption of future climate conditions. Streamflows can be forecast using the Extended Streamflow Prediction (ESP) technique in MMS, which is based on a modified version of the National Weather Service ESP program (Day, 1985; Leavesley and others, 1996). In the precipitation-runoff model for this study, ESP can be used to forecast the probability of streamflows for as far as 1 year in the future by assuming that historical records of daily precipitation and air temperatures will recur with the same probability as in the past. For example, if near-realtime initial conditions have been simulated for March 31 of a particular year and streamflows need to be predicted for the following April, the model will be run multiple times in the ESP mode for March 31 through April 30. Each run will have a different set of historical climate data for April but the same initial conditions for March 31. The resulting simulated daily streamflows for April can be analyzed further to determine 
probabilistic forecasts of variables of interest, such as the probability distribution of peak flow and total flow volume. An alternative use of ESP includes constraining forecasts by using only historical climate data that represent specific conditions, such as El Niño conditions. Use of the calibrated model is facilitated by a user-friendly Object User Interface (OUI) similar to that described for the Yakima River Basin precipitation-runoff model by Mastin and Vaccaro (2002b).

\section{Time-Series Data}

The precipitation-runoff model requires input time series of measured or estimated daily precipitation and daily minimum and maximum air temperatures. In addition, time series of measured or estimated streamflow are needed to calibrate the model.

\section{Precipitation and Air Temperature}

Historical records of daily precipitation and minimum and maximum air temperatures were obtained from different sources, including the National Weather Service (Hydrosphere Data Products, 2005), Natural Resources Conservation Service (U.S. Department of Agriculture, 2006), and Reclamation (Bureau of Reclamation, 2006a and 2006c). The climate stations used in this study are listed in table 2 and shown in figure 1.

Real-time inputs of precipitation and air temperature are required by the precipitation-runoff model to simulate realtime initial conditions for use in the ESP mode. Of the stations used in this study, only the Conconully CCR Hydromet, Omak OMAW AgriMet, and Salmon Meadows SNOTEL stations provide real-time data. The first water year for which complete sets of daily air temperature and precipitation data are available for two of the real-time stations, Omak OMAW AgriMet and Salmon Meadows SNOTEL, is 1990 (table 2). The first water year for which complete sets of daily air temperature and precipitation data are available for all three of the real-time stations is 2000. For the Conconully CCR Hydromet station, real-time daily precipitation and minimum and maximum air temperatures for water years 2000-04 were used as input to the model. For the Omak OMAW AgriMet station, real-time daily precipitation for water years 1990-96 and minimum and maximum air temperatures for water years 1990-2004 were used as input to the model. For the Salmon Meadows SNOTEL station, real-time daily precipitation data for water years 1990-96 were used as input to the model. The daily minimum and maximum air temperatures were not used in the model because those data were questionable for April 21, 1999, through August 16, 2005 (S. Strachan, Natural Resources Conservation Service, written commun., 2006). The February 1989 through September 1998 data were used to compute minimum and maximum air temperature lapse rates between the Omak OMAW AgriMet and Salmon Meadows SNOTEL stations.
Model simulations of historical conditions used input time series based on climate data from non-real-time stations for water years 1949-89, from non-real-time and realtime stations for water years 1990-99, and from real-time stations for water years 2000-04. For the Conconully station, daily precipitation and daily minimum and maximum air temperatures for water years 1949-99 were used as input to the model. The daily precipitation record was missing 8 percent of the data for water years 1949-96 and 23 percent of the data for water years 1997-99. The daily minimum and maximum air-temperature records were missing 8 percent of the data for water years 1949-96 and 21 percent of the data for water years 1997-99. Water years 1997 through at least 2003 were missing data for most of the winter months (generally for November through February). The missing daily precipitation and minimum and maximum air temperatures were estimated for water years 1949-99 on the basis of all possible combinations of single and multiple linear regressions (with intercept zero for regressions of daily precipitation) between the Conconully station and either one or both of the other long-term stations, the Omak $4 \mathrm{~N}$ and the Winthrop $1 \mathrm{WSW}$ stations (fig. 1). The regression that had the highest coefficient of determination $\left(\mathrm{r}^{2}\right)$ for which all required independent variables were available was used to estimate the missing data.

Synthetically generated temperatures for the Omak OMAW AgriMet station were used as inputs to simulate historical conditions for water years 1949-89. Synthesized temperatures for the Omak OMAW AgriMet station were used in addition to measured temperatures for the Conconully station to assure continuous daily minimum and maximum air-temperature time series at one location for water years 1949-2004. The synthetic daily minimum and maximum air temperatures for the Omak OMAW Agrimet station were generated on the basis of all possible combinations of single and multiple linear regressions between that station and one to three long-term climate stations, the Conconully, Omak $4 \mathrm{~N}$, and Winthrop $1 \mathrm{WSW}$ stations, in the study area (fig. 1). Separate sets of regressions were performed for each month to account for seasonal shifts in temperature relations. For each month, the regression that had the highest coefficient of determination for which all required independent variables were available was used to estimate the air temperatures for the Omak OMAW AgriMet station.

Daily precipitation and minimum and maximum air temperatures for the real-time Conconully CCR Hydromet station were used as inputs to simulate historical conditions for water years 2000-04. For the purposes of this study, it was assumed that the daily precipitation and air temperatures measured for the Conconully CCR Hydromet station were equivalent to the daily precipitation and air temperatures measured for the Conconully station. This assumption was based on a comparison of monthly mean minimum and maximum air temperatures and monthly total precipitation when measurements were available for both stations, August 1999 through September 2003. During this period, however, 
Table 2. Climate stations used in model simulations or to estimate missing data.

[NWS, National Weather Service; NRCS, Natural Resources Conservation Service; Reclamation, Bureau of Reclamation. All stations record daily precipitation and daily minimum and maximum air temperature]

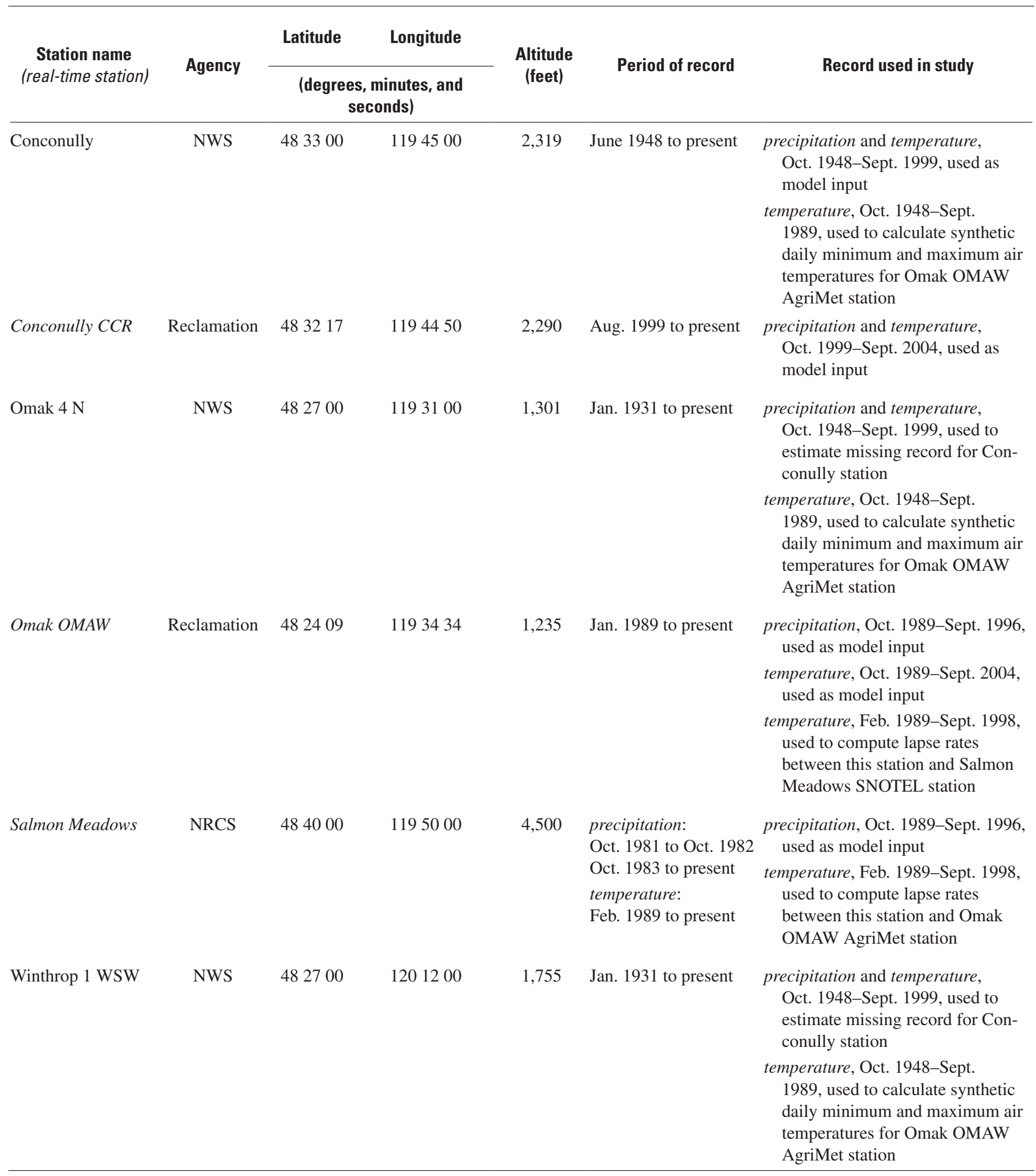


measurements were missing for the Conconully station from November through February. In 2003, the missing record extended through April. Linear regressions and plots of the data demonstrated that the monthly mean air temperatures and total precipitation compared well between the stations. The coefficient of determination was 0.99 for monthly mean minimum temperatures, 0.99 for monthly mean maximum temperatures, and 0.84 for monthly total precipitation for a linear regression with intercept zero. Because future measurements for the Conconully CCR Hydromet station will be used for simulating near-real-time initial hydrologic conditions for ESP forecasting, the precipitation-runoff model could be more reliable if the assumption of equivalency of air temperatures and precipitation between Conconully CCR Hydromet and Conconully climate stations could be confirmed using future, year-round data for a multiyear period for both stations.

\section{Streamflow}

Measured historical streamflows for Salmon Creek are limited to records for two USGS gages that were discontinued in the early 1900s, records for a Washington State Department of Ecology (DOE) gage that has been in operation since 2002, and records for a continuously recording gage operated by the OID since 2003 (T. Sullivan, Okanogan Irrigation District, oral commun., 2006). Prior to becoming a continuously recording gage in 2003, the OID gage was a staff gage that was read daily. The discontinued USGS gages are located just downstream of Conconully Reservoir (fig. 2; USGS station no. 12446500) and 6 mi upstream of the mouth of Salmon Creek (USGS station no. 12447000). The periods of record for the gages are water years 1912 through 1922 and 1904 through part of water year 1910, respectively. The DOE gage (DOE station no. 49M100) is located in North Fork Salmon Creek, about 2 mi upstream of the North Fork Diversion (fig. 2). The first complete April-July streamflow record was measured in water year 2004 and data for water year 2005 is currently (2006) provisional (Washington State Department of Ecology, 2006a; J. Shedd, Washington State Department of Ecology, written commun., 2006). The OID gage is located just upstream of the OID diversion in lower Salmon Creek (fig. 2). During periods of high snowmelt runoff in the spring, the OID gage is submerged and does not accurately measure streamflow for Salmon Creek. The OID also has measured diversions from Salmon Creek at the OID diversion since 1996 (Dames and Moore, 1999).

To expand the limited historical data set, Dames and Moore (1999) estimated a monthly time series of unregulated streamflow for Salmon Creek at Conconully Dam for 1904 through 1998 based on reservoir outflows and storage changes. The U.S. Department of Energy (2004) extended the estimates through 2002, and in this study, the estimates were extended through March 2006 (appendix 1) using storage and outflow data provided by the OID (T. Sullivan, Okanogan Irrigation District, written commun., 2006). The estimates represent unregulated streamflows for the upper Salmon Creek Basin (defined as the drainage area upstream of Conconully Dam), which encompasses 78 percent of the total drainage area of the basin.

The method used to estimate unregulated streamflow from reservoir outflows and storage changes has several potential sources of error. The first source of error is that the estimate does not include a correction for evaporative losses from Conconully Reservoir and the larger surface area of Salmon Lake Reservoir compared to the natural lake that was present prior to the construction of Salmon Lake Dam. Dames and Moore (1999) estimated that those evaporative losses are about $2.2 \mathrm{ft}^{3} / \mathrm{s}$ or about 1,600 acre-ft/yr. A second source of error is measurement error in the estimation of reservoir storage. Reservoir storage is estimated by measuring the stage in a reservoir and then converting the stage to a storage volume by using a stage-storage relation. Even small errors in measuring the stage can lead to significant errors in estimating the storage volume and, thus, to significant errors in estimating the monthly storage changes. Such errors may help explain why some estimates of monthly runoff are negative (Dames and Moore, 1999). For example, Dames and Moore (1999) suggested that stage-reading errors that resulted from wave run-up caused by wind may amount to storage-volume estimate errors of several hundred acre-ft. During a period of months, however, the errors in the estimates of monthly storage change are expected to cancel each other.

A third source of error in the estimation of unregulated streamflow is measurement error in reservoir outflow. Dames and Moore (1999) reported that prior to 1997, reservoir outflow was measured periodically by a weir located in Salmon Creek a few hundred feet downstream of Conconully Dam. This measurement included water that seeped below the dam, scheduled releases from the reservoir, and uncontrolled spills during periods of high runoff. Measurements of uncontrolled spills, however, are considered approximate (Dames and Moore, 1999; U.S. Department of Energy, 2004). Starting in 1997, the weir no longer was used and reservoir releases were measured only through the outlet tunnel. As a result, the measurements no longer include seepage below the dam [estimated to be about $1.6 \mathrm{ft}^{3} / \mathrm{s}$ or 100 acre-ft per month by Dames and Moore (1999)] and uncontrolled spills.

Dames and Moore (1999) indicated significant, unexplained discrepancies existed between the measured outflow from Conconully Reservoir and streamflow measured at the OID diversion. They attributed the discrepancies to probable errors in the measured outflows from Conconully Reservoir. Starting in 1997, the reliability of the estimates of runoff from upper Salmon Creek Basin becomes less certain than in previous years. Therefore, only data through water year 1996 were used in this study to calibrate and test the precipitation-runoff model.

A fourth source of error in the estimation of unregulated streamflow is that Conconully Reservoir overlies relatively permeable sediments through which ground-water recharge may occur. Some of the recharged ground water may leave 
Salmon Creek Basin through subsurface flow because the surface-water drainage boundary to the southeast of Conconully Reservoir in the Graveyard Flat area (fig. 2) is unlikely to be a ground-water divide during current (2006) hydrologic conditions. Therefore, some ground water is expected to flow southeasterly towards Scotch Creek. This interpretation is based on water-level altitude data for surfacewater features adjacent to the Graveyard Flat area and wells in the Graveyard Flat area. The water-level altitude data may indicate the raised water level of Conconully Reservoir above the natural creek bed may have created a hydraulic connection between the reservoir, the water-table aquifer below Graveyard Flat, and Scotch Creek. Too few data currently are available to determine whether a similar hydraulic connection may have existed prior to the creation of Conconully Reservoir. However, even if a hydraulic connection did exist, groundwater losses would have been significantly smaller during unregulated conditions than during current conditions.

In summary, the estimated streamflows for the upper Salmon Creek Basin, including estimates prior to 1997, have several potential sources of error. However, the estimates are the best available and, therefore, were used in this study as a surrogate for the missing long-term unregulated streamflows for Salmon Creek at the current location of Conconully Dam. The time series of unregulated streamflows is referred to as uncorrected unregulated streamflow (UUS) in this report.

\section{Corrected Unregulated Streamflow}

A second time series of unregulated streamflow for Salmon Creek at Conconully Dam was generated by adding estimates of ground-water losses and evaporative losses to the uncorrected time series. The corrected time series is expressed as

$$
C U S=U U S+G W+R E S \_E V A P,
$$

where

CUS is corrected unregulated streamflow, in cubic feet per second;

UUS is uncorrected unregulated streamflow, in cubic feet per second;

$G W$ is the ground-water flux, in cubic feet per second, from Salmon Creek Basin; and

$R E S \_E V A P$ is reservoir evaporation, in cubic feet per second.

As described in the sections "Corrections for GroundWater Losses" and "Corrections for Evaporative Losses," the ground-water flux from the basin $(G W)$ is estimated to be about $2 \mathrm{ft}^{3} / \mathrm{s}$ and reservoir evaporation $\left(R E S \_E V A P\right)$ is estimated to be about $1 \mathrm{ft}^{3} / \mathrm{s}$. The total of the corrections is about 9 percent of the long-term mean UUS, which is $32.2 \mathrm{ft}^{3} / \mathrm{s}(23,300$ acre-ft/yr) for water years 1949-96. On an annual basis, the sum of the estimated ground-water flux and reservoir evaporation also represents about 9 percent of the total maximum active storage capacity of 23,500 acre-ft for Conconully and Salmon Lake Reservoirs.

\section{Corrections for Ground-Water Losses}

Conconully Reservoir possibly recharges the underlying ground-water system and part of the recharged water may leave Salmon Creek Basin through subsurface flow in the general direction of Scotch Creek (fig. 2). The surficial geology between Conconully Reservoir and the headwaters of Scotch Creek is mapped as Continental Glacial Drift deposits (Stoffel, 1990). Driller's logs obtained from the Washington State Department of Ecology (2006b) for two wells in the Graveyard Flat area show a relatively thick sequence of sedimentary deposits that is likely underlain by a former bedrock valley (field-verification of well locations was beyond the scope of this study). The saturated sediments, which start at about 115 to $130 \mathrm{ft}$ below land surface, consist of sand, gravels, and some clay. Based on the lithologic and water-level information from these logs, it is estimated that the Graveyard Flat area is underlain by at least $70 \mathrm{ft}$ of saturated sediments. Assuming horizontal flow, Darcy's law states that ground-water flux can be estimated as follows:

$$
Q=K A i
$$

where

$Q$ is ground-water discharge, in cubic feet per day;

$K$ is horizontal hydraulic conductivity of the sediments, in feet per day;

$A$ is cross-sectional area perpendicular to the direction of flow, in square feet; and

$i$ is hydraulic gradient (dimensionless).

The hydraulic conductivity $(K)$ of the saturated glacial-drift materials is estimated to be $40 \mathrm{ft} / \mathrm{d}$, which is a conservatively low estimate based on hydraulic conductivities calculated for permeable glacial sediments elsewhere in Washington State (for example, Kahle, 1998; and Kahle and others, 2003). [In a summary of hydraulic-conductivity estimates for glacial sediments from multiple sources, Fetter (1994) reported that glacial-outwash deposits can have hydraulic conductivities that range from about $3 \mathrm{ft} / \mathrm{d}$ to about 3,000 ft/d depending on the degree of sorting of the sediments.] Assuming the cross-sectional area through which the southeasterly-flowing ground water discharges is $2,000 \mathrm{ft}$ wide and $70 \mathrm{ft}$ thick, the cross-sectional area perpendicular to the direction of flow $(A)$ is $140,000 \mathrm{ft}^{2}$. A mean hydraulic gradient $(i)$ of 0.03 was computed by assuming a water level of 2,282 $\mathrm{ft}$ for Conconully Reservoir and by assuming the water table intersects the land surface at 2,110 ft in the headwaters of Scotch Creek, where the creek first becomes a perennial stream according to the 1:24,000-scale topographic map for the area. Using these estimates in equation 2 , about $2 \mathrm{ft}^{3} / \mathrm{s}$ (about 1,400 acre-ft/yr) of ground water discharges from upper Salmon Creek Basin in a southeasterly direction. Some of this ground water likely discharges to Scotch Creek while the remainder is likely to travel along longer and deeper flowpaths and become incorporated in the regional ground-water flow system. 
Currently available data are insufficient to determine whether ground-water losses occurred prior to the creation of Conconully Reservoir or, if losses did occur, to determine the rate of the losses. If ground-water losses did occur, however, they would have been significantly smaller than the losses estimated for current conditions. Therefore, for this study, out-of-basin ground-water losses were assumed to be negligible during unregulated conditions.

\section{Corrections for Evaporative Losses}

The construction of Conconully and Salmon Lake Reservoirs introduced evaporative losses from the reservoir surfaces as an additional source of water loss from the basin. For the purpose of this study, the increase in evaporative losses from Salmon Lake Reservoir was ignored because Salmon Lake Reservoir is located in a narrow canyon and the conversion of Salmon Lake to Salmon Lake Reservoir was assumed to result in a relatively small increase in watersurface area. The construction of Conconully Reservoir, however, created a relatively shallow water body that has a maximum size of about 400 acres where previously only a stream and natural vegetation were present.

Farnsworth and others (1982) estimated, on the basis of regional data collected from 1956 through 1970, an annual free-water-surface evaporation of about 30 in. at the location of Conconully Reservoir. They also estimated that about 23 in., or 77 percent of the annual total, evaporates from May through October. Monthly estimates of reference evapotranspiration for alfalfa at the Omak OMAW AgriMet station (Bureau of Reclamation, 2006a) for water years 1990-2004 range from 0.6 percent of the mean annual total in December to 19.9 percent in July (fig. 7). From May through October, the reference evapotranspiration for alfalfa is $36.5 \mathrm{in}$., or 81.5 percent of the mean annual total of $44.8 \mathrm{in}$.

Assuming that the reservoir is at a maximum size of 400 acres during May through July, 200 acres during April and August, and 100 acres during the remainder of the year, and that the annual evaporation is 30 in. distributed according to the monthly reference evapotranspiration at the Omak OMAW AgriMet station, the annual evaporative loss from Conconully Reservoir is estimated to be about $1 \mathrm{ft}^{3} / \mathrm{s}$ (about 700 acre-ft) (table 3). Different assumptions for the values of annual freewater-surface evaporation and monthly reservoir surface area could alter the estimate significantly.

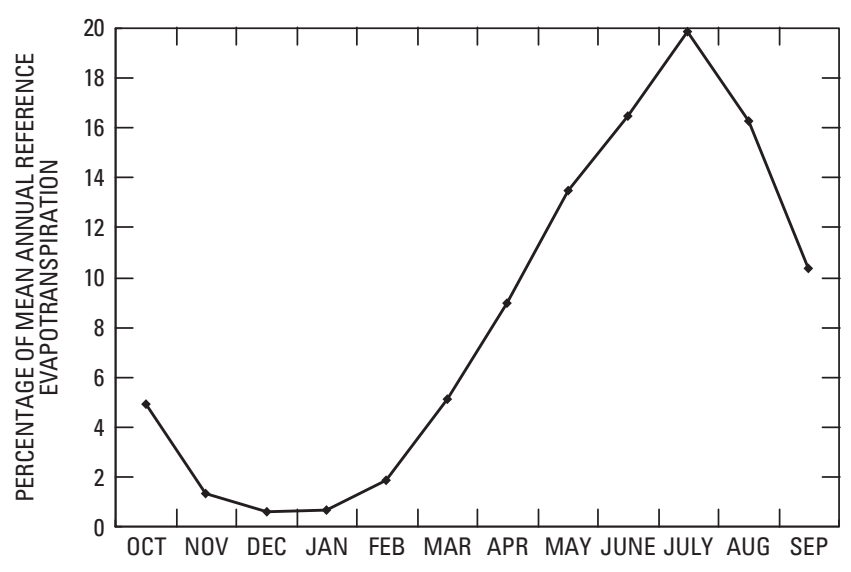

Figure 7. Mean monthly reference evapotranspiration as a percentage of mean annual reference evapotranspiration for alfalfa (1982 Kimberly-Penman equation) at the Omak OMAW AgriMet station, water years 1990-2004.

Table 3. Estimated evaporation from Conconully Reservoir, assuming a mean annual free-water-surface evaporation of 30 inches.

[ft $\mathrm{ft}^{3} / \mathrm{s}$, cubic feet per second; acre-ft, acre-feet]

\begin{tabular}{|c|c|c|c|c|c|}
\hline \multirow{2}{*}{ Month } & \multirow{2}{*}{$\begin{array}{l}\text { Estimated } \\
\text { surface area } \\
\text { of Conconully } \\
\text { Reservoir } \\
\text { (acres) }\end{array}$} & \multirow{2}{*}{$\begin{array}{l}\text { Percentage } \\
\text { of annual } \\
\text { evaporation }\end{array}$} & \multicolumn{3}{|c|}{ Evaporation } \\
\hline & & & (inches) & $\left(\mathrm{ft}^{3} / \mathrm{s}\right)$ & (acre-ft) \\
\hline October & 100 & 4.9 & 1.5 & 0.20 & 12 \\
\hline November & 100 & 1.3 & 0.39 & 0.054 & 3.3 \\
\hline December & 100 & 0.6 & 0.18 & 0.025 & 1.5 \\
\hline January & 100 & 0.7 & 0.21 & 0.028 & 1.7 \\
\hline February & 100 & 1.8 & 0.55 & 0.076 & 4.6 \\
\hline March & 100 & 5.1 & 1.5 & 0.21 & 13 \\
\hline April & 200 & 9.0 & 2.7 & 0.75 & 45 \\
\hline May & 400 & 13.5 & 4.0 & 2.2 & $1.4 \times 10^{2}$ \\
\hline June & 400 & 16.5 & 5.0 & 2.7 & $1.7 \times 10^{2}$ \\
\hline July & 400 & 19.9 & 6.0 & 3.3 & $2.0 \times 10^{2}$ \\
\hline August & 200 & 16.3 & 4.9 & 1.4 & 82 \\
\hline September & 100 & 10.4 & 3.1 & 0.43 & 26 \\
\hline \multicolumn{2}{|c|}{ Annual mean } & & 30 & 1.0 & $6.9 \times 10^{2}$ \\
\hline
\end{tabular}




\section{Delineation of Basin Physical Characteristics}

Salmon Creek Basin was subdivided into 179 MRUs (fig. 8) using a tool called the GIS (Geographic Information System) Weasel (Viger and others, 1998) and manually adding separate MRUs for Conconully and Salmon Lake Reservoirs. The GIS Weasel is a computer program that allows easy generation of MRUs and a drainage network (fig. 8) on the basis of a digital elevation model (DEM). The computer program also creates initial model input parameters for each MRU on the basis of a variety of digital geographic data, including soils, land use, and vegetation type and density.

The MRUs and drainage network were delineated according to the same procedures used by Ely and Risley (2001) and Ely (2003) in the precipitation-runoff study of the Methow River Basin. The differences are that, in the current study, a higher-resolution DEM was used for the delineation of the MRUs and drainage network and the selection of different delineation thresholds resulted in generally smaller MRUs and a more detailed drainage network.

The MRUs and drainage network were delineated on the basis of a DEM that had a cell size of $33 \mathrm{ft}(10 \mathrm{~m})$ by $33 \mathrm{ft}$. An initial set of MRUs was generated by considering the range of slopes (fig. 9) and aspects in the basin. This set of MRUs then was subdivided by applying the GIS Weasel two-plane option, which creates separate MRUs on each side of a stream segment. A first-order stream was assumed to drain at least 35,000 DEM cells or an area of $1.35 \mathrm{mi}^{2}$ ( 865 acres). The set of MRUs then was subdivided a second time by partitioning the basin into eight equal-elevation bands of $930 \mathrm{ft}$ to account for the large elevation range in the basin. This process created some very small MRUs that then were merged with neighboring, larger MRUs. The merging of MRUs recombined a few MRUs on opposite sides of the streams. The final 179 MRUs range in size from 141 to 1,971 acres and have a mean size of 544 acres. For comparison, the 620 MRUs in the precipitation-runoff study of the Methow River Basin range in size from 596 to 7,370 acres and have a mean size of 1,870 acres.

\section{Model Parameterization}

Initial model parameters were assigned by applying the GIS Weasel (Viger and others, 1998), computing values from measured data, and using parameters from the Methow River Basin precipitation-runoff model (Ely and Risley, 2001; Ely, 2003). A subset of the parameters was adjusted during calibration to achieve a good fit between the simulated and measured or estimated variables, as described in the "Model Calibration and Testing" section of this report.

Using the GIS Weasel, mean slope, aspect, and elevation were assigned to each MRU on the basis of the DEM, soil characteristics were assigned on the basis of the State Soil Geographic (STATSGO) database (U.S. Department of Agriculture, 1994), and the dominant vegetation type and vegetation characteristics were assigned on the basis of National Land Cover Data (NLCD 92) (U.S. Geological Survey, 1992; Vogelmann and others, 2001; fig. 10) and digital maps of United States forest types and density (Powell and others, 1993; Zhu and Evans, 1992). Monthly mean minimum and maximum air-temperature lapse rates were computed from air temperatures for the Omak OMAW AgriMet and Salmon Meadows SNOTEL stations for February 1989 through September 1998. Parameters that represent the mean monthly rainfall or snowfall on each MRU were obtained from values computed with the Parameter-elevation Regressions on Independent Slopes Model (PRISM; Daly and others, 1994 and 2002; Daly and Johnson, 1999) for the climate-normal period of 1971-2000 (Spatial Climate Analysis ServiceOregon State University, 2006). The precipitation-runoff model for this study distributes daily precipitation measured at climate stations across the model area according to the ratios between monthly PRISM values and monthly precipitation at the climate stations and weighted by the inverse of the square of the distance to the climate stations.

The model simulates streamflow for 11 locations (fig. 11) distributed at the mouths of subbasins (nodes 2 through 6), at the mouth of the entire basin (node 11), at points of diversion (nodes 1 and 10), and at three additional locations in lower Salmon Creek (nodes 7 through 9). Node 6, which represents Salmon Creek at the location of Conconully Dam, captures streamflow generated in upper Salmon Creek Basin. 


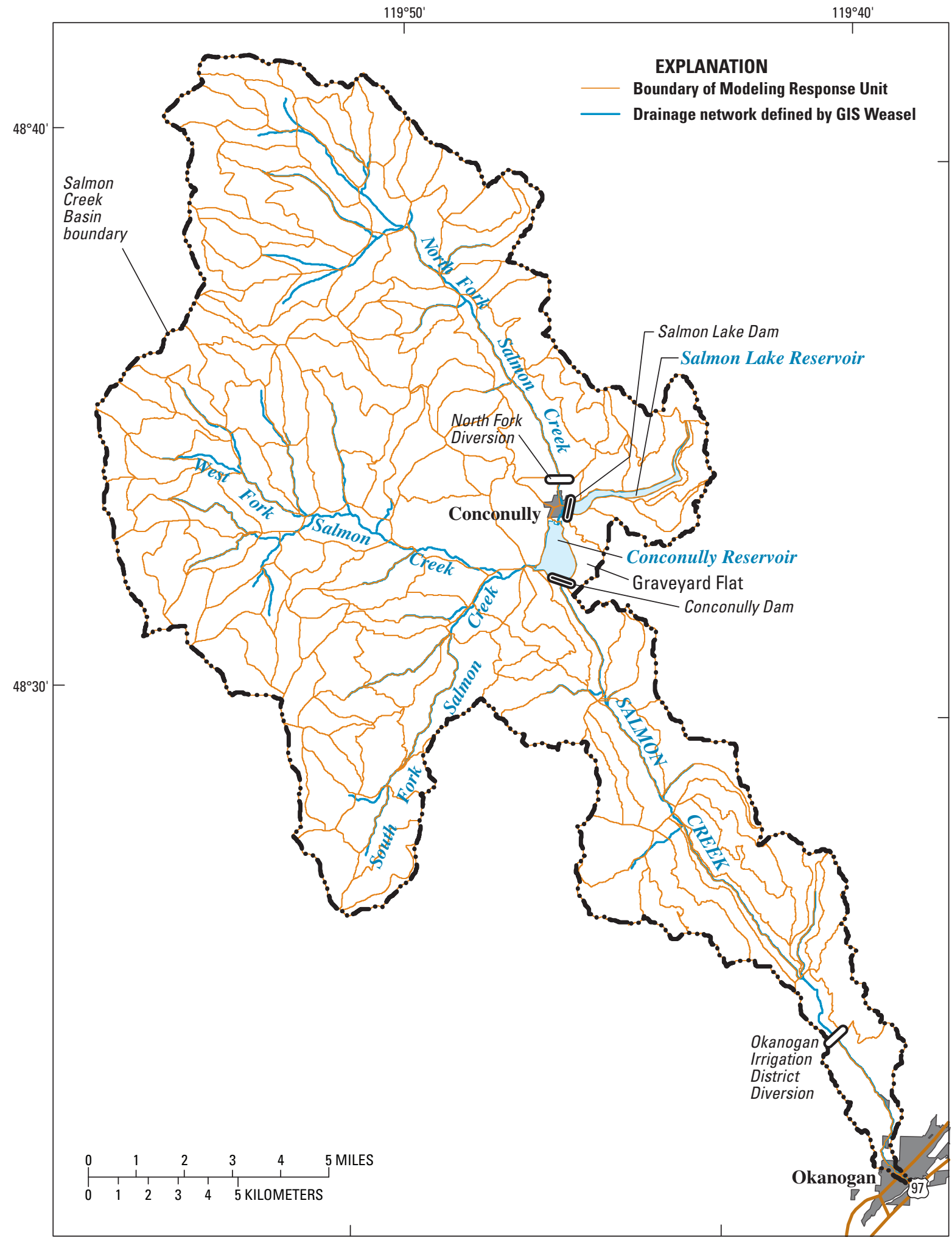

Base map modified from USGS digital data 1:100,000, 1995

Hillshade modified from National Elevation Dataset, 2000, 10-meter resolution

Universal Transverse Mercator projection, zone 11,

North American Datum of 1983, North American Vertical Datum of 1988

Figure 8. Modeling Response Units and drainage network delineated for the precipitation-runoff model for the Salmon Creek Basin, Okanogan County, Washington. 


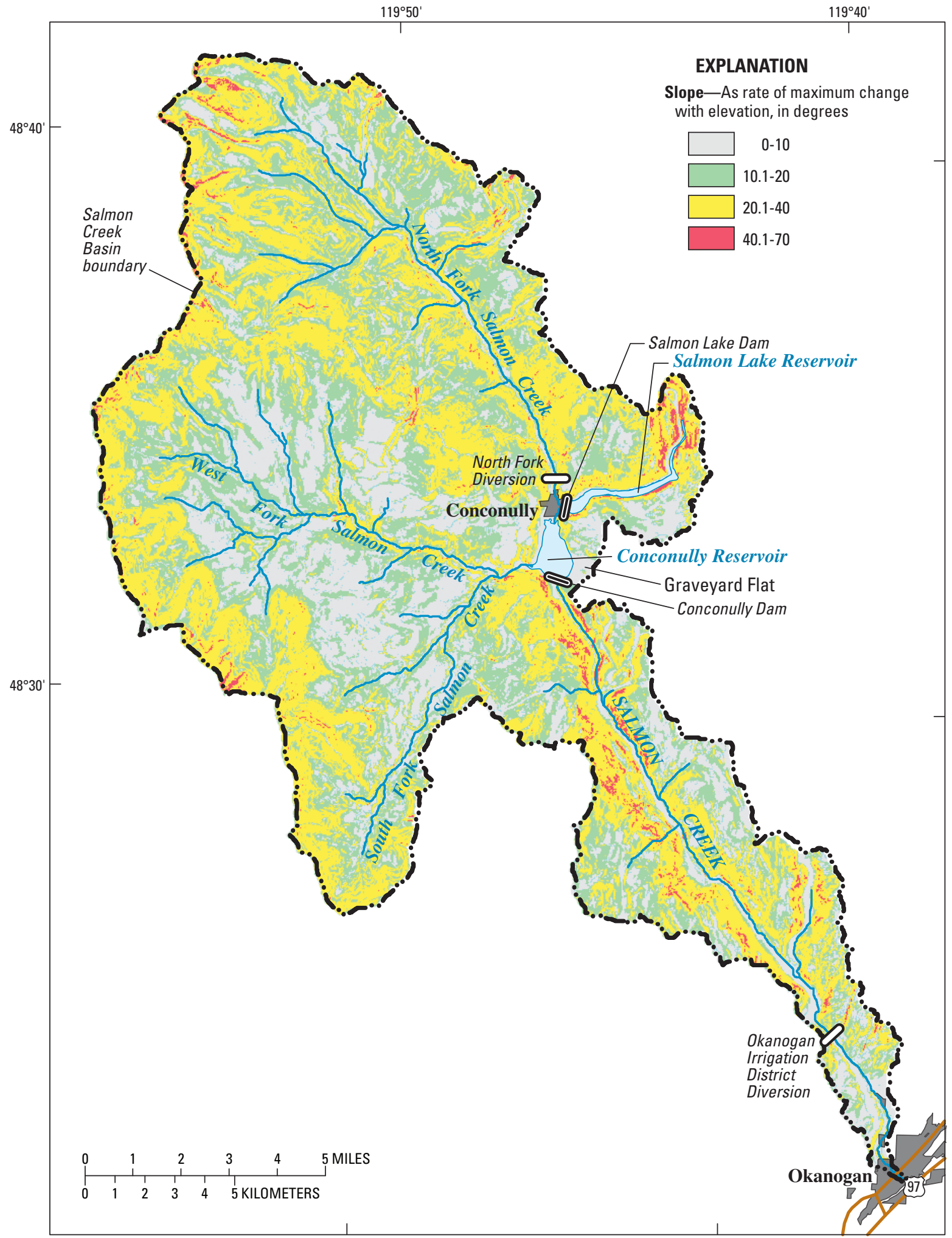

Base map modified from USGS digital data 1:100,000, 1995

Hillshade modified from National Elevation Dataset, 2000, 10-meter resolution

Universal Transverse Mercator projection, zone 11,

North American Datum of 1983, North American Vertical Datum of 1988

Figure 9. Generalized slopes in the Salmon Creek Basin, Okanogan County, Washington. 


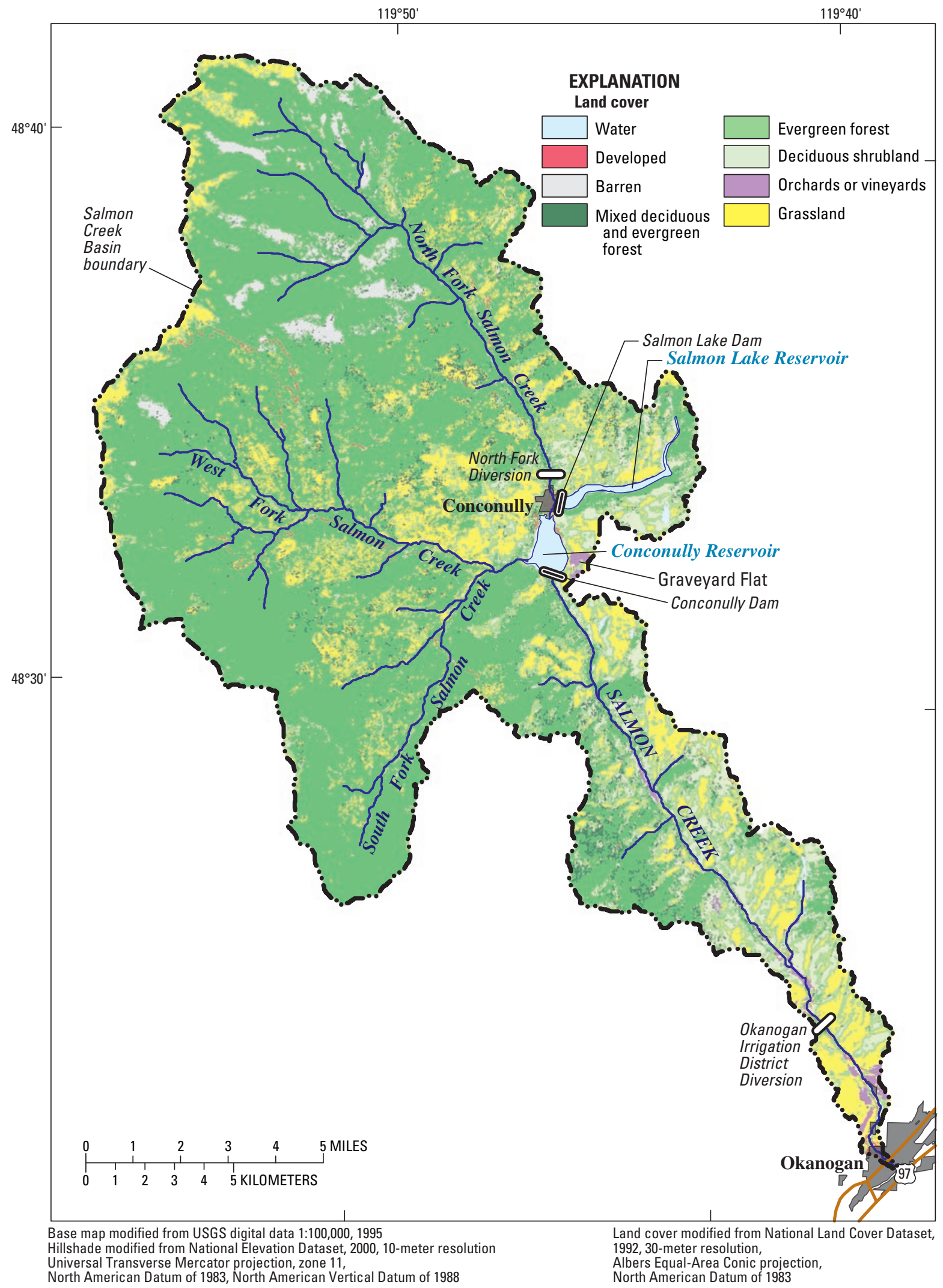

Figure 10. Land cover in the Salmon Creek Basin, Okanogan County, Washington. 


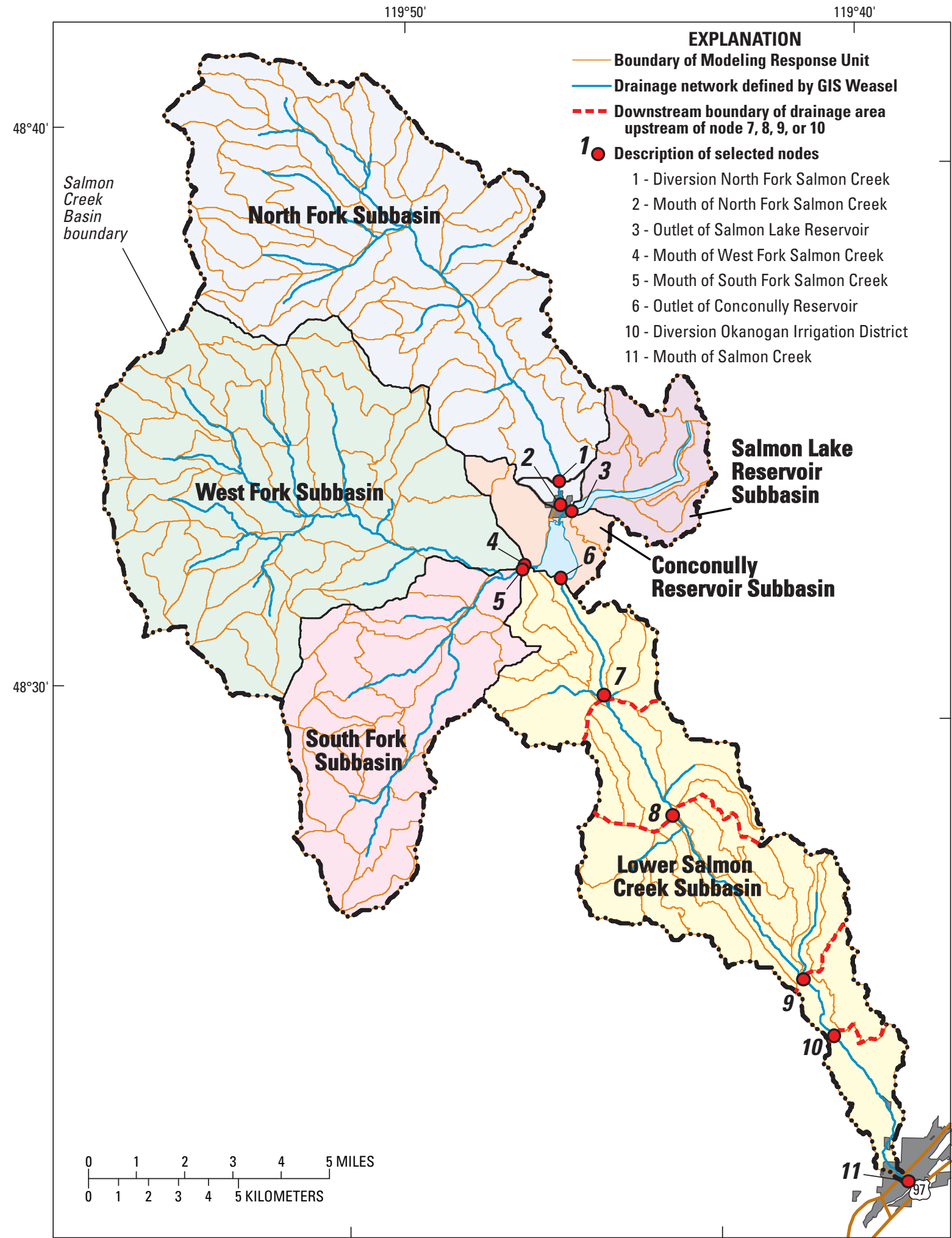

Base map modified from USGS digital data 1:100,000, 1995

Hillshade modified from National Elevation Dataset, 2000, 10-meter resolution

Universal Transverse Mercator projection, zone 11,

North American Datum of 1983, North American Vertical Datum of 1988

Figure 11. Major subbasins and locations of model nodes in the Salmon Creek Basin, Okanogan County, Washington. 


\section{Model Calibration and Testing}

The precipitation-runoff model was calibrated for a 40-year period, water years 1950-89, and tested for a 7-year period, water years 1990-96 (table 4). The actual model simulations used data for water years 1949-89, but results of the first year were not included in the calibration analysis to allow the model to properly initialize basinwide hydrologic conditions for that year. The goal of the calibration effort was to adjust the initial model parameters so that the simulated monthly unregulated streamflows for Salmon Creek at the location of Conconully Dam (node 6; fig. 11) were more than the estimated UUS and less than the estimated CUS. The model was tested by using the calibrated parameter values to simulate streamflows for a period not used for calibration and then comparing the results for node 6 with the UUS and CUS.

As explained in the "Corrected Unregulated Streamflow" section, CUS includes a correction for ground-water losses from the Salmon Creek Basin and evaporative losses from Conconully Reservoir. The precipitation-runoff model as applied in this study does not simulate ground-water losses but does simulate a fraction of reservoir evaporation up to the amount of precipitation that falls on the reservoir. For example, a mean annual evaporation of $18.9 \mathrm{in}$. was simulated for Conconully Reservoir for the calibration period, and the long-term mean annual reservoir evaporation is estimated to be 30 in. (table 3). As a result, the model is considered calibrated if simulated streamflows are larger than UUS but smaller than CUS.

During model calibration, model parameters were adjusted from initial values as follows: Parameter jh_coef, which helps determine the rate of potential evapotranspiration as computed with the Jensen-Haise approach (Jensen and Haise, 1963; Mastin and Vaccaro, 2002a), was increased by 25 percent for each month compared to the values used in the Methow River Basin model. This increased the basinwide simulated mean annual actual evapotranspiration for water years $1950-89$ by $1.7 \mathrm{in}$. and generated a simulated mean annual water budget that matched the estimated mean annual water budget. For water years 1950-89, the basinwide simulated mean annual precipitation and evapotranspiration were 23.1 and 19.1 in., respectively. The high evapotranspiration rates are reasonable given the extensive forests in the Salmon Creek Basin.

The minimum and maximum air-temperature time series for each MRU were lowered by increasing parameters tmin_adj and tmax_adj from 0 to $7^{\circ} \mathrm{F}$ each month. The lower temperatures resulted in a simulated mean hydrograph that best matched the shape of the UUS/CUS hydrograph for the calibration period. The date when the model starts looking for spring snowmelt was delayed by 20 days to April 20 by changing parameter melt_look from a Julian date of
90 to 110 . However, simulated snowmelt still started too early in the runoff season. Therefore, the initial monthly mean minimum and maximum air-temperature lapse rates computed from measured air temperatures for the Omak OMAW Agrimet and Salmon Meadows SNOTEL stations were reduced by $2.5^{\circ} \mathrm{F}$ per $1,000 \mathrm{ft}$ in March (to -5.58 and $-7.32^{\circ} \mathrm{F}$ per $1,000 \mathrm{ft}$, respectively) and $1.5^{\circ} \mathrm{F}$ per $1,000 \mathrm{ft}$ in April (to -4.47 and $-6.61^{\circ} \mathrm{F}$ per $1,000 \mathrm{ft}$, respectively) to further delay the onset of melting, and the lapse rates were increased by $0.5^{\circ} \mathrm{F}$ per $1,000 \mathrm{ft}$ in May (to -2.76 and $-4.15^{\circ} \mathrm{F}$ per $1,000 \mathrm{ft}$, respectively) to increase the rate of snowmelt. The monthly lapse rates were kept constant throughout the model simulations. Finally, parameter freeh2o_cap, the free-water-holding capacity of the snowpack, expressed as a decimal fraction of the snowpack water-equivalent, was reduced 50 percent to 0.025 to help improve the shape of the hydrograph from May through July.

The results of the model calibration are shown in figures $12 \mathrm{~A}$ and $13 \mathrm{~A}$ through $\underline{13 \mathrm{D}}$ and are given in table 5 . For the calibration period, water years 1950-89, both the simulated mean annual streamflow and the simulated mean April-July streamflow compare well with the estimated values for UUS and CUS. The simulated mean annual streamflow exceeds UUS by 5.9 percent and is less than CUS by 2.7 percent (table 5). Similarly, the simulated mean April-July streamflow exceeds UUS by 1.8 percent and is less than CUS by 3.1 percent. A comparison of the estimated and simulated mean monthly streamflows, however, shows that streamflow is significantly undersimulated during the low-flow, baseflow-dominated months of November through February when simulated monthly streamflows are as much as 57.2 percent less than UUS (table 5) and significantly oversimulated during August and September when simulated monthly streamflows are as much as 193.6 percent more than CUS (table 5). During the low-flow months, however, estimated mean monthly streamflow is only a small percentage of the estimated mean annual streamflow, about 2 percent in November through February and about 1 percent in August and September (fig. 12A). Therefore, the absolute errors during the low-flow months are relatively small even though the percentages of error are large. For April through July, the estimated mean streamflow is about 84 percent of the estimated mean annual streamflow (fig. 12A). Because the simulated spring snowmelt season starts too early in April and extends too far into July (fig. 12A), the simulated streamflows exceed the estimated streamflows in April and July and are less than the estimated streamflows in May and June (table 5). Because the precipitation-runoff model will be used primarily as a tool to manage spring runoff, model calibration focused on matching estimated and simulated mean April-July streamflow rather than streamflows for individual months. 
Table 4. Periods of simulation and model input time series for each type of model simulation.

\begin{tabular}{|c|c|c|c|}
\hline $\begin{array}{l}\text { Type of model } \\
\text { simulation }\end{array}$ & Period of simulation & Model input time series & Remarks \\
\hline CALIBRATION & Oct. 1948 - Sept. 1989 & $\begin{array}{l}\text { Daily precipitation and minimum and } \\
\text { maximum air temperatures for Conconully } \\
\text { climate station } \\
\text { Synthetic daily minimum and } \\
\text { maximum air temperatures for } \\
\text { Omak OMAW AgriMet station }\end{array}$ & Oct. 1948 - Sept. 1949 omitted from analysis \\
\hline TESTING 1 & Oct. 1989 - Sept. 1996 & $\begin{array}{l}\text { Daily precipitation and minimum and maxi- } \\
\text { mum air temperatures for Conconully } \\
\text { climate station } \\
\text { Daily minimum and maximum air tempera- } \\
\text { tures for Omak OMAW AgriMet station }\end{array}$ & $\begin{array}{l}\text { Differs from CALIBRATION in that measured, real- } \\
\text { time air temperatures are used instead of synthetic } \\
\text { air temperatures for Omak OMAW AgriMet } \\
\text { station }\end{array}$ \\
\hline TESTING 3 & Oct. 1989 - Sept. 1996 & $\begin{array}{l}\text { Daily precipitation and minimum and } \\
\text { maximum air temperatures for Conconully } \\
\text { climate station and Omak OMAW AgriMet } \\
\text { station }\end{array}$ & $\begin{array}{l}\text { Differs from TESTING } 1 \text { in that measured, real-time } \\
\text { precipitation data for Omak OMAW AgriMet sta- } \\
\text { tion are added }\end{array}$ \\
\hline TESTING 4 & Oct. 1989 - Sept. 1996 & $\begin{array}{l}\text { Daily precipitation and minimum and } \\
\text { maximum air temperatures for Conconully } \\
\text { climate station and Omak OMAW AgriMet } \\
\text { station } \\
\text { Daily precipitation for Salmon Meadows } \\
\text { SNOTEL station }\end{array}$ & $\begin{array}{l}\text { Differs from TESTING } 1 \text { in that measured, real-time } \\
\text { precipitation data for Salmon Meadows SNOTEL } \\
\text { and Omak OMAW AgriMet stations are added }\end{array}$ \\
\hline
\end{tabular}



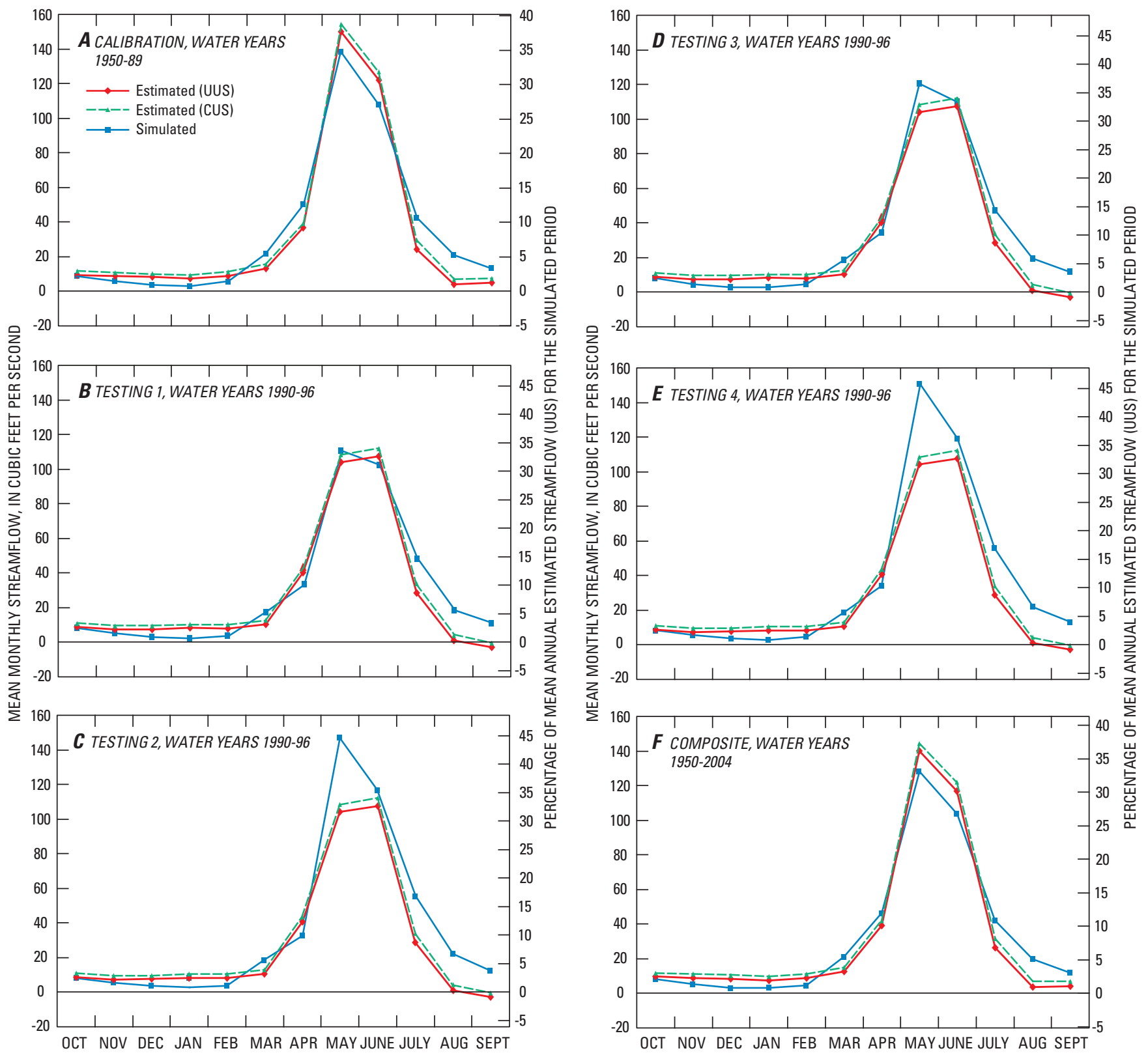

Figure 12. Estimated and simulated mean monthly unregulated streamflows for Salmon Creek at Conconully Dam, Okanogan County, Washington. (UUS is uncorrected unregulated streamflow; CUS is corrected unregulated streamflow.) 

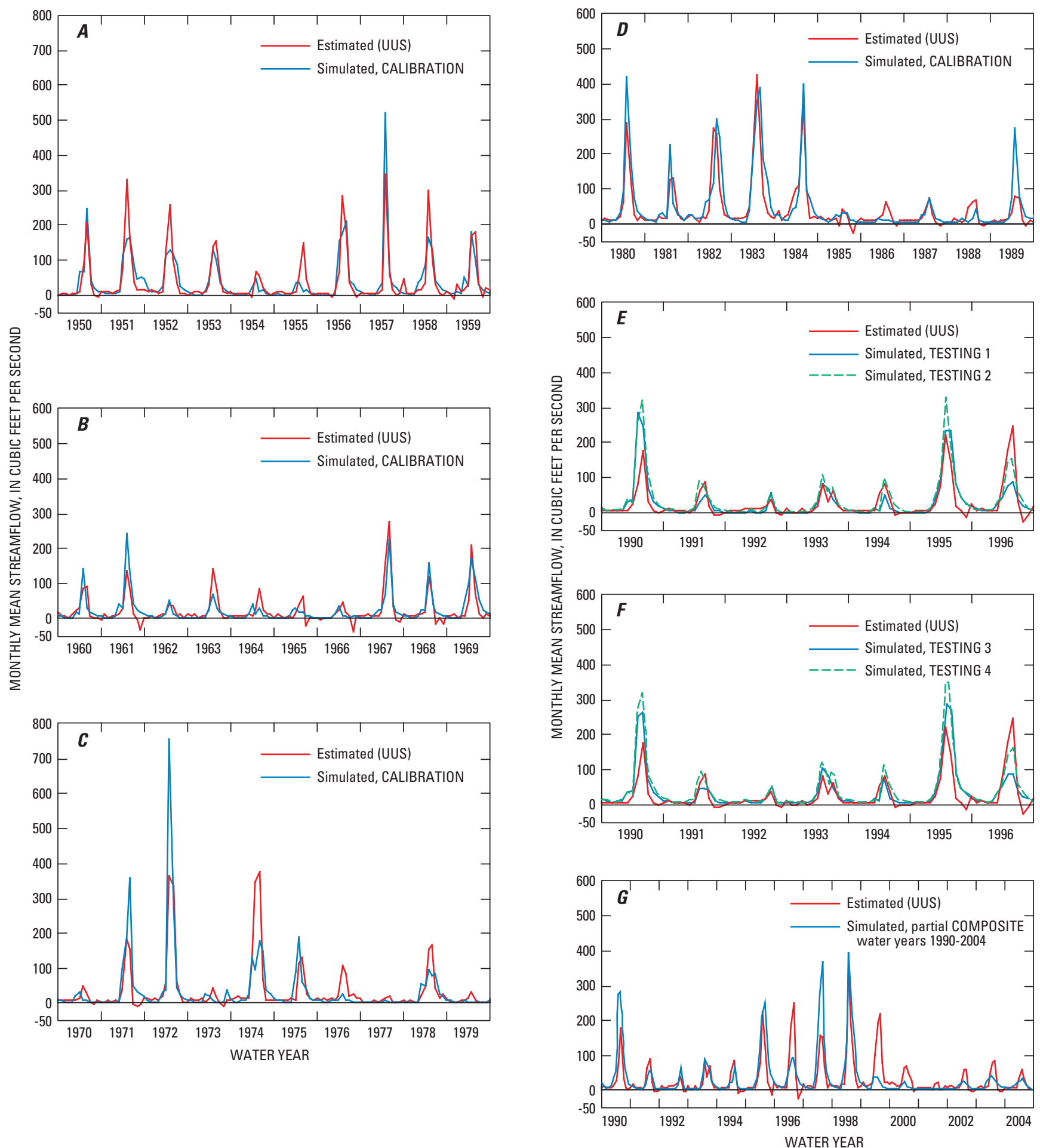

Figure 13. Time series of estimated and simulated monthly mean unregulated streamflows for Salmon Creek at Conconully Dam, Okanogan County, Washington. (UUS is uncorrected unregulated streamflow.) 
Table 5. Mean monthly, annual, and April-July estimated and simulated unregulated streamflows for Salmon Creek at Conconully Dam and the percentage of error for the CALIBRATION, TESTING 1, TESTING 2, TESTING 3, TESTING 4, and COMPOSITE model simulations.

[UUS, uncorrected unregulated streamflow; CUS, corrected unregulated streamflow; Percentage of error with respect to UUS or CUS: Values may not match presented values because of rounding; CALIBRATION: Model simulations are based on input time series of daily precipitation and minimum and maximum air temperatures for Conconully climate station and synthetic daily minimum and maximum air temperatures for Omak OMAW AgriMet station; TESTING 1: Model simulations are based on input time series of daily precipitation and minimum and maximum air temperatures for Conconully climate station and daily minimum and maximum air temperatures for Omak OMAW AgriMet station; TESTING 2: Model simulations are based on input time series of daily precipitation and minimum and maximum air temperatures for Conconully climate station, daily minimum and maximum air temperatures for Omak OMAW AgriMet station, and daily precipitation for Salmon Meadows SNOTEL station; TESTING 3: Model simulations are based on input time series of daily precipitation and minimum and maximum air temperatures for Conconully climate station and Omak OMAW AgriMet station; TESTING 4: Model simulations are based on input time series of daily precipitation and minimum and maximum air temperatures for Conconully climate station and Omak OMAW AgriMet station and daily precipitation for Salmon Meadows SNOTEL station; COMPOSITE: Model simulations are based on input time series of daily precipitation and minimum and maximum air temperatures for Conconully climate station and synthetic daily minimum and maximum air temperatures for Omak OMAW AgriMet station for water years 1950-89, daily precipitation and minimum and maximum air temperatures for Conconully climate station and daily minimum and maximum air temperatures for Omak OMAW AgriMet station for water years 1990-99, and daily precipitation and minimum and maximum air temperatures for Conconully CCR Hydromet station and daily minimum and maximum air temperatures for Omak OMAW AgriMet station for water years 2000-04; percentage of error = $100 \times($ simulated - estimated $) /$ estimated. Unit abbreviation: $\mathrm{ft}^{3} / \mathrm{s}$, cubic foot per second]

\begin{tabular}{|c|c|c|c|c|c|}
\hline \multirow[t]{2}{*}{ Time period } & \multicolumn{2}{|c|}{ Mean estimated } & \multirow{2}{*}{$\begin{array}{c}\text { Mean } \\
\text { simulated } \\
\text { unregulated } \\
\text { streamflow } \\
\left(\mathrm{ft}^{3} / \mathrm{s}\right)\end{array}$} & \multicolumn{2}{|c|}{$\begin{array}{l}\text { Percentage of } \\
\text { error with } \\
\text { respect to }\end{array}$} \\
\hline & $\begin{array}{c}\text { UUS } \\
\left(\mathrm{ft}^{3} / \mathbf{s}\right)\end{array}$ & $\begin{array}{c}\text { CUS } \\
\left(\mathrm{ft}^{3} / \mathbf{s}\right)\end{array}$ & & UUS & CUS \\
\hline \multicolumn{6}{|c|}{ CALIBRATION, water years 1950-89 } \\
\hline October & 9.5 & 11.7 & 8.6 & -9.2 & -26.0 \\
\hline November & 8.8 & 10.9 & 5.6 & -36.1 & -48.2 \\
\hline December & 8.2 & 10.2 & 3.6 & -56.2 & -64.7 \\
\hline January & 7.3 & 9.3 & 3.1 & -57.2 & -66.3 \\
\hline February & 9.0 & 11.2 & 5.6 & -37.6 & -50.0 \\
\hline March & 13.4 & 15.6 & 21.7 & 61.9 & 39.5 \\
\hline April & 36.6 & 39.3 & 50.4 & 37.7 & 28.0 \\
\hline May & 149.9 & 154.0 & 138.5 & -7.6 & -10.1 \\
\hline June & 122.1 & 126.8 & 107.3 & -12.1 & -15.4 \\
\hline July & 24.4 & 29.6 & 42.5 & 74.4 & 43.8 \\
\hline August & 3.8 & 7.1 & 20.9 & 445.1 & 193.6 \\
\hline September & 5.2 & 7.6 & 13.0 & 151.9 & 70.7 \\
\hline Annual $^{1}$ & 33.3 & 36.2 & 35.2 & 5.9 & -2.7 \\
\hline April-July ${ }^{1}$ & 83.3 & 87.5 & 84.8 & 1.8 & -3.1 \\
\hline
\end{tabular}

TESTING 1, water years 1990-96

\begin{tabular}{|c|c|c|c|c|c|}
\hline October & 8.9 & 11.0 & 8.0 & -9.8 & -27.4 \\
\hline November & 7.4 & 9.4 & 4.8 & -35.5 & -49.7 \\
\hline December & 7.5 & 9.5 & 3.1 & -58.2 & -66.9 \\
\hline January & 8.3 & 10.3 & 2.4 & -71.6 & -77.1 \\
\hline February & 8.1 & 10.4 & 3.4 & -58.6 & -67.5 \\
\hline March & 10.6 & 12.7 & 17.8 & 68.5 & 39.9 \\
\hline April & 40.5 & 43.3 & 33.3 & -17.9 & -23.1 \\
\hline May & 104.2 & 108.3 & 110.5 & 6.0 & 2.0 \\
\hline June & 107.3 & 112.1 & 102.4 & -4.5 & -8.6 \\
\hline July & 28.6 & 33.8 & 48.3 & 68.5 & 42.7 \\
\hline August & 0.9 & 4.2 & 18.4 & $1,866.6$ & 337.0 \\
\hline September & -2.9 & 0.5 & 11.2 & -481.0 & $2,380.6$ \\
\hline Annual $^{1}$ & 27.5 & 30.4 & 30.4 & 10.7 & 0.0 \\
\hline April-July ${ }^{1}$ & 70.1 & 74.3 & 73.7 & 5.1 & -0.8 \\
\hline
\end{tabular}

\begin{tabular}{|c|c|c|c|c|c|}
\hline \multirow[t]{2}{*}{ Time period } & \multicolumn{2}{|c|}{ Mean estimated } & \multirow{2}{*}{$\begin{array}{c}\text { Mean } \\
\text { simulated } \\
\text { unregulated } \\
\text { streamflow } \\
\left(\mathrm{ft}^{3} / \mathrm{s}\right)\end{array}$} & \multicolumn{2}{|c|}{$\begin{array}{l}\text { Percentage of } \\
\text { error with } \\
\text { respect to }\end{array}$} \\
\hline & $\begin{array}{l}\text { UUS } \\
\left(\mathbf{f t}^{3} / \mathbf{s}\right)\end{array}$ & $\begin{array}{c}\text { CUS } \\
\left(\mathrm{ft}^{3} / \mathrm{s}\right)\end{array}$ & & UUS & CUS \\
\hline \multicolumn{6}{|c|}{ TESTING 2, water years 1990-96 } \\
\hline October & 8.9 & 11.0 & 8.4 & -5.3 & -23.8 \\
\hline November & 7.4 & 9.4 & 5.2 & -29.1 & -44.6 \\
\hline December & 7.5 & 9.5 & 3.4 & -54.8 & -64.2 \\
\hline January & 8.3 & 10.3 & 2.6 & -68.7 & -74.7 \\
\hline February & 8.1 & 10.4 & 3.8 & -53.7 & -63.6 \\
\hline March & 10.6 & 12.7 & 18.4 & 74.1 & 44.5 \\
\hline April & 40.5 & 43.3 & 32.3 & -20.4 & -25.5 \\
\hline May & 104.2 & 108.3 & 146.5 & 40.6 & 35.3 \\
\hline June & 107.3 & 112.1 & 116.8 & 8.9 & 4.2 \\
\hline July & 28.6 & 33.8 & 55.8 & 94.8 & 64.9 \\
\hline August & 0.9 & 4.2 & 21.8 & $2,226.1$ & 416.9 \\
\hline September & -2.9 & -0.5 & 12.8 & -535.2 & $-2,704.7$ \\
\hline Annual $^{1}$ & 27.5 & 30.4 & 35.8 & 30.4 & 17.8 \\
\hline April-July ${ }^{1}$ & 70.1 & 74.3 & 88.1 & 25.6 & 18.5 \\
\hline
\end{tabular}

TESTING 3, water years 1990-96

\begin{tabular}{|c|c|c|c|c|c|}
\hline October & 8.9 & 11.0 & 8.0 & -10.0 & -27.5 \\
\hline November & 7.4 & 9.4 & 4.9 & -34.1 & -48.5 \\
\hline December & 7.5 & 9.5 & 3.2 & -56.6 & -65.7 \\
\hline January & 8.3 & 10.3 & 2.7 & -67.4 & -73.6 \\
\hline February & 8.1 & 10.4 & 5.0 & -39.1 & -52.2 \\
\hline March & 10.6 & 12.7 & 18.5 & 74.9 & 45.2 \\
\hline April & 40.5 & 43.3 & 34.1 & -15.8 & -21.2 \\
\hline May & 104.2 & 108.3 & 120.9 & 16.1 & 11.6 \\
\hline June & 107.3 & 112.1 & 109.6 & 2.1 & -2.2 \\
\hline July & 28.6 & 33.8 & 47.9 & 67.3 & 41.6 \\
\hline August & 0.9 & 4.2 & 19.2 & $1,954.1$ & 356.5 \\
\hline September & -2.9 & -0.5 & 11.6 & -494.1 & $-2,459.0$ \\
\hline Annual $^{1}$ & 27.5 & 30.4 & 32.3 & 17.4 & 6.0 \\
\hline April-July ${ }^{1}$ & 70.1 & 74.3 & 78.2 & 11.6 & 5.3 \\
\hline
\end{tabular}


Table 5. Mean monthly, annual, and April-July estimated and simulated unregulated streamflows for Salmon Creek at Conconully Dam and the percentage of error for the CALIBRATION, TESTING 1, TESTING 2, TESTING 3, TESTING 4, and COMPOSITE model simulations.-Continued

[UUS, uncorrected unregulated streamflow; CUS, corrected unregulated streamflow; Percentage of error with respect to UUS or CUS: Values may not match presented values because of rounding; CALIBRATION: Model simulations are based on input time series of daily precipitation and minimum and maximum air temperatures for Conconully climate station and synthetic daily minimum and maximum air temperatures for Omak OMAW AgriMet station; TESTING 1: Model simulations are based on input time series of daily precipitation and minimum and maximum air temperatures for Conconully climate station and daily minimum and maximum air temperatures for Omak OMAW AgriMet station; TESTING 2: Model simulations are based on input time series of daily precipitation and minimum and maximum air temperatures for Conconully climate station, daily minimum and maximum air temperatures for Omak OMAW AgriMet station, and daily precipitation for Salmon Meadows SNOTEL station; TESTING 3: Model simulations are based on input time series of daily precipitation and minimum and maximum air temperatures for Conconully climate station and Omak OMAW AgriMet station; TESTING 4: Model simulations are based on input time series of daily precipitation and minimum and maximum air temperatures for Conconully climate station and Omak OMAW AgriMet station and daily precipitation for Salmon Meadows SNOTEL station; COMPOSITE: Model simulations are based on input time series of daily precipitation and minimum and maximum air temperatures for Conconully climate station and synthetic daily minimum and maximum air temperatures for Omak OMAW AgriMet station for water years 1950-89, daily precipitation and minimum and maximum air temperatures for Conconully climate station and daily minimum and maximum air temperatures for Omak OMAW AgriMet station for water years 1990-99, and daily precipitation and minimum and maximum air temperatures for Conconully CCR Hydromet station and daily minimum and maximum air temperatures for Omak OMAW AgriMet station for water years 2000-04; percentage of error = $100 \times\left(\right.$ simulated - estimated)/estimated. Unit abbreviation: $\mathrm{ft}^{3} / \mathrm{s}$, cubic foot per second]

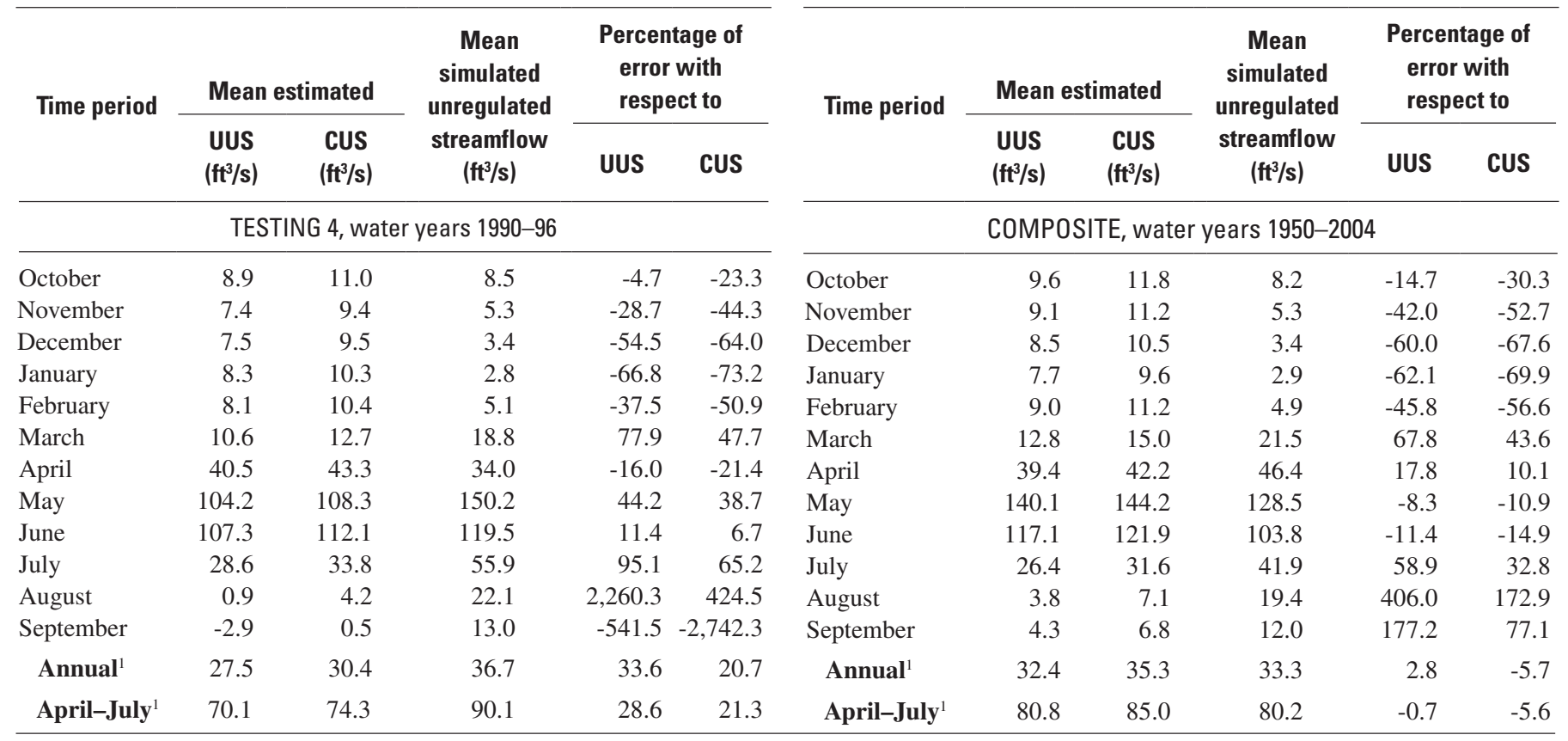

${ }^{1}$ Values may not match presented values because of rounding.

The precipitation-runoff model was tested for water years 1990-96 using measured daily precipitation and minimum and maximum air temperatures for the Conconully station and measured daily minimum and maximum air temperatures for the Omak OMAW AgriMet station. The data set used for this testing is referred to as "TESTING 1" (figs. $12 B$ and $\underline{13 E}$; tables 4 and $\underline{5}$ ). The difference between the input time series for TESTING 1 and the input time series for model calibration is that measured temperatures are used instead of synthetic temperatures.

For TESTING 1, the model simulated a close fit for the mean annual streamflow and a good fit for the mean April-July streamflow. The simulated mean annual streamflow exceeds UUS by 10.7 percent and is the same as CUS (table 5). The simulated mean April-July streamflow exceeds UUS by 5.1 percent and is less than CUS by 0.8 percent (table 5). The testing results indicate that the precipitationrunoff model is adequately calibrated for the purpose of simulating annual mean and April-July mean streamflows.

The precipitation-runoff model was tested three more times to determine if adding different combinations of daily precipitation to the input time series for TESTING 1 for two of the real-time stations, Omak OMAW AgriMet and Salmon Meadows SNOTEL, would improve the fit between estimated and simulated streamflows for water years 1990-96. For TESTING 2, daily precipitation for Salmon Meadows 
SNOTEL station was added to the input time series for TESTING 1; for TESTING 3, daily precipitation for Omak OMAW AgriMet station was added to the input time series for TESTING 1; and for TESTING 4, daily precipitation for Salmon Meadows SNOTEL and Omak OMAW AgriMET stations was added to the input time series for TESTING 1 (table 4). Results of TESTING 2, TESTING 3, and TESTING 4 are shown in figures $12 C$ through $\underline{12 E}, \underline{13 E}$, and $\underline{13 F}$ and are given in table 5 .

For TESTING 2, TESTING 3, and TESTING 4, the simulated mean annual and mean April-July streamflows were significantly larger than the estimated streamflows. The oversimulation was largest for TESTING 4 and smallest for TESTING 3. The simulated mean annual streamflow for TESTING 4 exceeds CUS by 20.7 percent (compared to 17.8 percent for TESTING 2 and 6.0 percent for TESTING 3 ), and the simulated mean April-July streamflow for TESTING 4 exceeds CUS by 21.3 percent (compared to 18.5 percent for TESTING 2 and 5.3 percent for TESTING 3). The testing results indicate that adding precipitation data for two of the real-time stations, Omak OMAW AgriMet and Salmon Meadows SNOTEL, to the input time series of the calibrated precipitation-runoff model does not improve simulated annual mean and April-July mean streamflows.

A final comparison between estimated and simulated streamflows was made for the entire simulation period, water years 1950-2004. The input time series used for this simulation is referred to as "COMPOSITE" and is identical to the input time series for model calibration (water years 1950-89) and for TESTING 1 (water years 1990-96). For water years 1997-2004, the input time series consists of data for the same climate stations as CALIBRATION and TESTING 1, except that for water years 2000-04 daily precipitation and minimum and maximum air temperatures are used for the real-time Conconully CCR Hydromet station instead of Conconully climate station. When using the precipitation-runoff model for ESP forecasting, Reclamation will expand the COMPOSITE data set to include the most recent real-time input time-series data for Conconully CCR Hydromet station (daily precipitation and air temperatures) and Omak OMAW AgriMet station (daily air temperatures only) for simulating near-real-time hydrologic conditions in the Salmon Creek Basin. For COMPOSITE, the model simulated a good fit for the mean annual streamflow and a close fit for the mean April-July streamflow (figs. $12 \mathrm{~F}$ and $\underline{13 G}$; table 5). The simulated mean annual streamflow exceeds UUS by 2.8 percent and is less than CUS by 5.7 percent (table 5). The simulated mean April-July streamflow is less than UUS by 0.7 percent and less than CUS by 5.6 percent (table 5). The model simulated a better fit for mean April, June, and July streamflow for COMPOSITE than for CALIBRATION. Simulated mean April streamflow exceeds CUS by 10.1 percent for COMPOSITE and 28.0 percent for CALIBRATION. Simulated mean June streamflow is less than UUS by 11.4 percent for COMPOSITE and 12.1 percent for CALIBRATION. Simulated mean July streamflow exceeds CUS by 32.8 percent for COMPOSITE and 43.8 percent for CALIBRATION. A comparison of the estimated and simulated annual mean streamflows for CALIBRATION, TESTING 1, and COMPOSITE is shown in figure 14.

The simulated mean annual basinwide precipitation amount during the 40-year calibration period, 1950-89, was $23.1 \mathrm{in}$. and ranged from $11.8 \mathrm{in}$. for water year 1979 to $41.3 \mathrm{in}$. for water year 1983. During the driest 4 water years $(1964,1977,1979$, and 1985), the model simulated poor fits for the annual mean streamflows and April-July mean streamflows. Simulated annual mean streamflow is less than UUS by 81.3 percent in water year $1977,46.8$ percent in water year 1964, and 42.9 percent in water year 1979 (fig. 14; table 6). In water year 1985, simulated annual mean streamflow exceeds CUS by 31.2 percent. Simulated April-July mean streamflow is less than UUS by 74.8 percent in water year 1977, 74.2 percent in water year 1979, and 39.7 percent in water year 1964 (table 6). In water year 1985, simulated April-July mean streamflow exceeds CUS by 24.0 percent. The large percentages of error are with respect to relatively small estimated annual mean and April-July mean streamflows for Salmon Creek at Conconully Dam. When comparing undersimulated streamflow with respect to UUS and oversimulated streamflow with respect to CUS, the absolute errors range from an undersimulation of annual mean streamflow of $8.0 \mathrm{ft}^{3} / \mathrm{s}$ in water year 1964 to an oversimulation of annual mean streamflow of $3.4 \mathrm{ft}^{3} / \mathrm{s}$ in water year 1985 (table 6). Similarly, the absolute errors range from an undersimulation of April-July mean streamflow with respect to UUS of $13.6 \mathrm{ft}^{3} / \mathrm{s}$ in water year 1964 to an oversimulation of April-July mean streamflow with respect to CUS of $4.2 \mathrm{ft}^{3} / \mathrm{s}$ in water year 1985 (table 6).

During the wettest 4 water years (1951, 1971, 1982, and 1983), the model also simulated poor fits for the annual mean streamflows and April-July mean streamflows. Simulated annual mean streamflow exceeds CUS by 73.3 percent in water year 1971, 17.4 percent in water year 1983, and 15.0 percent in water year 1982 (table 6). In water year 1951, simulated annual mean streamflow is less than UUS by 4.7 percent (fig. 14). Simulated April-July mean 


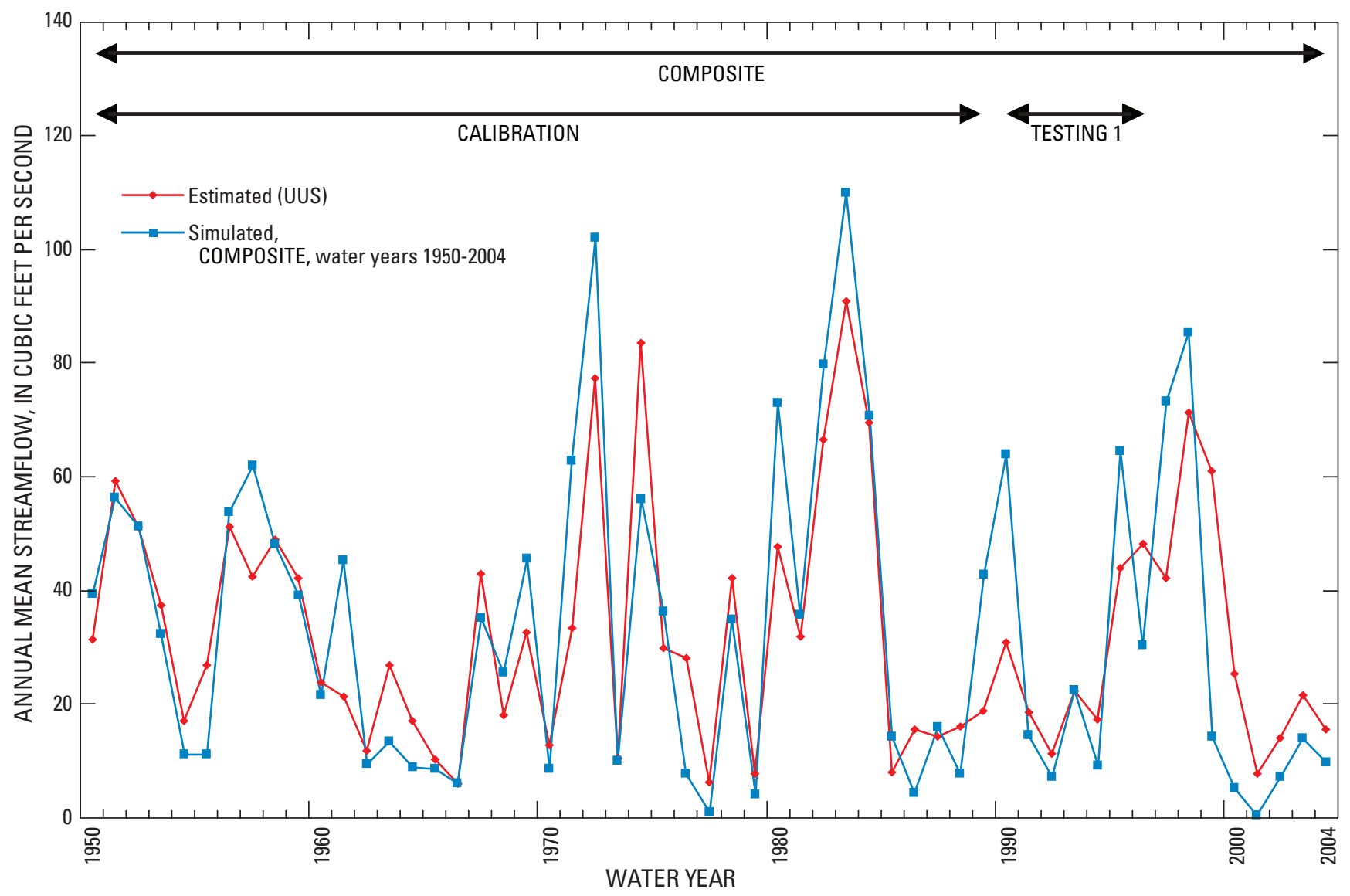

Figure 14. Time series of estimated and simulated annual mean unregulated streamflows for Salmon Creek at Conconully Dam, Okanogan County, Washington. (UUS is uncorrected unregulated streamflow.)

streamflow exceeds CUS by 75.6 percent in water year 1971, 13.7 percent in water year 1983 , and 6.7 percent in water year 1982 (table 6). In water year 1951, simulated April-July mean streamflow is less than UUS by 13.1 percent. When comparing undersimulated streamflow with respect to UUS and oversimulated streamflow with respect to CUS, the absolute errors range from an undersimulation of annual mean streamflow of $2.8 \mathrm{ft}^{3} / \mathrm{s}$ in water year 1951 to an oversimulation of annual mean streamflow of $26.6 \mathrm{ft}^{3} / \mathrm{s}$ in water year 1971 . Similarly, the absolute errors range from an undersimulation of April-July mean streamflow with respect to UUS of 19.8 $\mathrm{ft}^{3} / \mathrm{s}$ in water year 1951 to an oversimulation of April-July mean streamflow with respect to CUS of $74.1 \mathrm{ft}^{3} / \mathrm{s}$ in water year 1971 (table 6).
In addition to the estimated streamflow data for Salmon Creek at Conconully Dam that were available for calibration and testing, snowpack water-equivalent data are available for the Salmon Meadows SNOTEL station for water year 1982 and for water years 1984 to the present (2006). A comparison of measured and simulated mean monthly snowpack waterequivalents for TESTING 1, TESTING 2, TESTING 3, and TESTING 4 (fig. 15A and $\underline{15 B}$ ) and the partial COMPOSITE for water years 1990-2004 (fig. 15C) indicates the model oversimulates the overall snowpack water-equivalent for the Salmon Meadows SNOTEL station and delays the simulated timing of spring snowmelt by 1 month. If snowpack melting throughout upper Salmon Creek Basin is simulated to occur according to the pattern for the Salmon Meadows SNOTEL 
Table 6. Annual mean and April-July mean estimated and unregulated streamflows for Salmon Creek at Conconully Dam for the driest 4 water years and wettest 4 water years, 1950-89, and the percentage of error and the absolute error for the model simulations.

[UUS, uncorrected unregulated streamflow; CUS, corrected unregulated streamflow; percentage of error $=100 \mathrm{x}\left(\right.$ simulated - estimated)/estimated; $\mathrm{ft}^{3} / \mathrm{s}$, cubic foot per second; in/yr, inch per year]

\begin{tabular}{|c|c|c|c|c|c|c|c|c|c|}
\hline \multirow{2}{*}{ Time period } & \multicolumn{2}{|c|}{$\begin{array}{c}\text { Mean simulated } \\
\text { basinwide precipitation }\end{array}$} & \multicolumn{2}{|c|}{ Mean estimated } & \multirow{2}{*}{$\begin{array}{c}\text { Mean simulated } \\
\text { unregulated } \\
\text { streamflow } \\
\left(\mathrm{ft}^{3} / \mathrm{s}\right)\end{array}$} & \multicolumn{2}{|c|}{$\begin{array}{l}\text { Percentage of error } \\
\text { with respect to }\end{array}$} & \multicolumn{2}{|c|}{$\begin{array}{l}\text { Absolute error } \\
\text { with respect to }\end{array}$} \\
\hline & (in/yr) & $\left(\mathrm{ft}^{3} / \mathrm{s}\right)$ & $\begin{array}{l}\text { UUS } \\
\left(\mathrm{ft}^{3} / \mathrm{s}\right)\end{array}$ & $\begin{array}{l}\text { CUS } \\
\left(\mathrm{ft}^{3} / \mathbf{s}\right)\end{array}$ & & UUS & CUS & $\begin{array}{l}\text { UUS } \\
\left(\mathrm{ft}^{\mathrm{t}} / \mathrm{s}\right)\end{array}$ & $\begin{array}{c}\text { CUS } \\
\left(\mathrm{ft}^{3} / \mathbf{s}\right)\end{array}$ \\
\hline \multicolumn{10}{|c|}{ Driest 4 water years, 1950-89 } \\
\hline Water year 1979 & 11.8 & 132.1 & 7.7 & 10.7 & 4.4 & -42.9 & -58.9 & -3.3 & -6.3 \\
\hline April-July, 1979 & & & 12.4 & 16.6 & 3.2 & -74.2 & -80.7 & -9.2 & -13.4 \\
\hline Water year 1977 & 12.0 & 134.4 & 6.4 & 9.3 & 1.2 & -81.3 & -87.1 & -5.2 & -8.1 \\
\hline April-July, 1977 & & & 10.3 & 14.6 & 2.6 & -74.8 & -82.2 & -7.7 & -12.0 \\
\hline Water year 1964 & 14.6 & 163.5 & 17.1 & 20.0 & 9.1 & -46.8 & -54.5 & -8.0 & -10.9 \\
\hline April-July, 1964 & & & 34.3 & 38.5 & 20.7 & -39.7 & -46.2 & -13.6 & -17.8 \\
\hline Water year 1985 & 15.0 & 168.0 & 7.9 & 10.9 & 14.3 & 81.0 & 31.2 & 6.4 & 3.4 \\
\hline April-July, 1985 & & & 13.2 & 17.5 & 21.7 & 64.4 & 24.0 & 8.5 & 4.2 \\
\hline \multicolumn{10}{|c|}{ Wettest 4 water years, $1950-89$} \\
\hline Water year 1971 & 31.7 & 355.0 & 33.4 & 36.4 & 63.0 & 88.6 & 73.1 & 29.6 & 26.6 \\
\hline April-July, 1971 & & & 93.8 & 98.0 & 172.1 & 83.5 & 75.6 & 78.3 & 74.1 \\
\hline Water year 1951 & 32.5 & 364.0 & 59.3 & 62.2 & 56.5 & -4.7 & -9.2 & -2.8 & -5.7 \\
\hline April-July, 1951 & & & 151.7 & 155.9 & 131.9 & -13.1 & -15.4 & -19.8 & -24.0 \\
\hline Water year 1982 & 34.9 & 390.8 & 66.6 & 69.5 & 79.9 & 20.0 & 15.0 & 13.3 & 10.4 \\
\hline April-July, 1982 & & & 165.3 & 169.5 & 180.8 & 9.4 & 6.7 & 15.5 & 11.3 \\
\hline Water year 1983 & 41.3 & 462.5 & 90.9 & 93.8 & 110.1 & 21.1 & 17.4 & 19.2 & 16.3 \\
\hline April-July, 1983 & & & 233.1 & 237.3 & 269.7 & 15.7 & 13.7 & 36.6 & 32.4 \\
\hline
\end{tabular}

station, however, peak runoff for Salmon Creek at Conconully Dam would occur in April and May rather than May and June. Reasons for this discrepancy may be that conditions at the Salmon Meadows SNOTEL station may be sunnier or windier than the average for all MRUs in upper Salmon Creek Basin. A comparison of measured and simulated monthly mean snowpack water-equivalent at the Salmon Meadows SNOTEL station for TESTING 1 and a partial COMPOSITE for water years 1990-2004 is shown in figure 16. The extent to which the fit between the measured and simulated snowpack waterequivalent is representative of the entire basin is unknown because the snowpack measurement for the Salmon Meadows SNOTEL station represents only one point. 

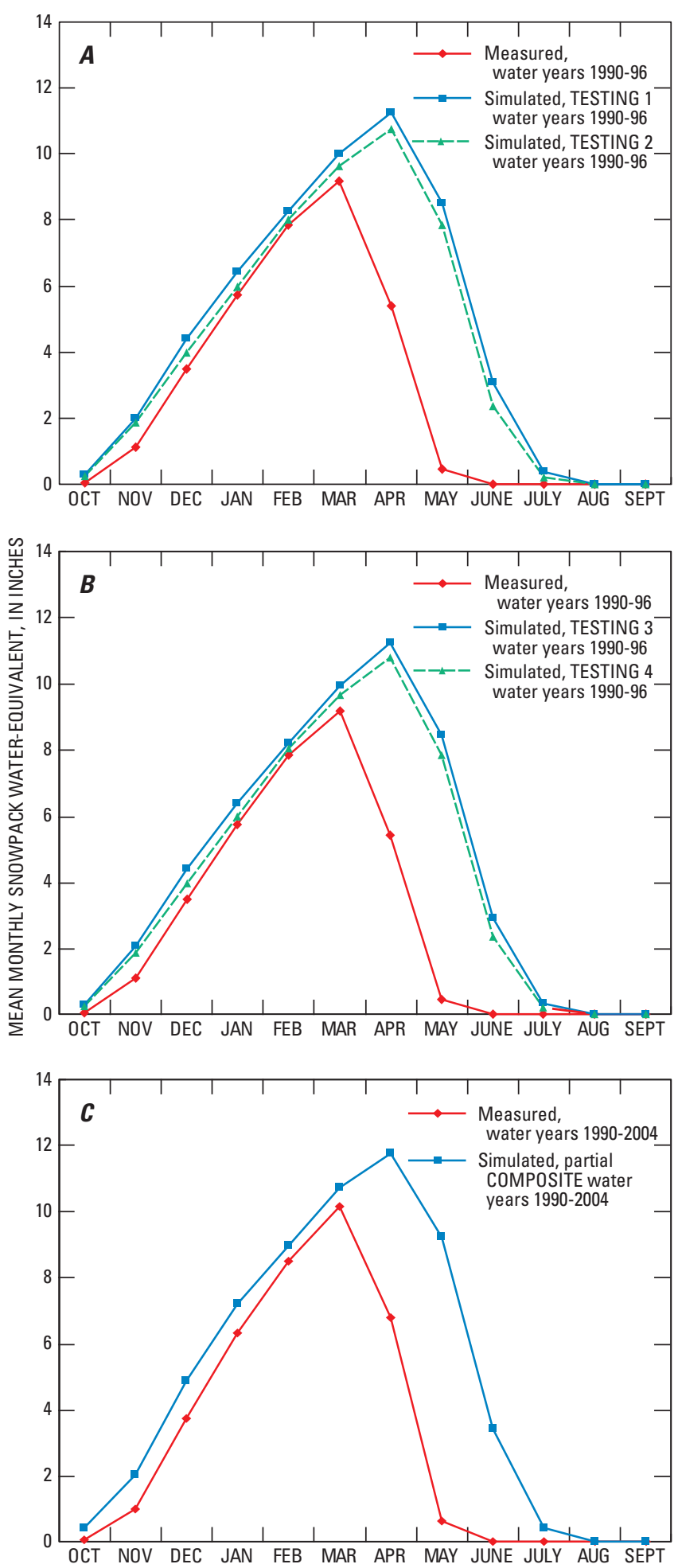

Figure 15. Measured and simulated mean monthly snowpack water-equivalent for the Salmon Meadows SNOTEL station, Okanogan County, Washington.

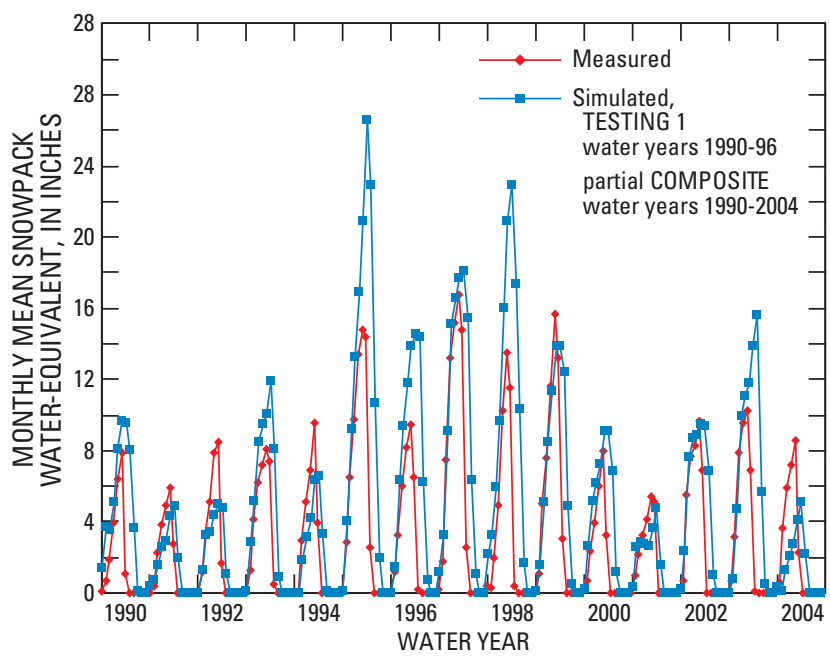

Figure 16. Time series of measured and simulated monthly mean snowpack water-equivalent for the Salmon Meadows SNOTEL station, Okanogan County, Washington.

\section{Model Limitations}

The precipitation-runoff model is a mathematical representation of the physical processes that occur in the Salmon Creek Basin. As a result, the quality of the model results depends on the accuracy of the mathematical representation of the physical processes (model error), the quality and accuracy of the precipitation and air-temperature input time series and the streamflow calibration/testing time series (data error), and the accuracy of the calibrated model parameters (parameter error). Model calibration and testing indicate that daily streamflows simulated using the precipitation-runoff model described in this report should be used only to analyze historical and forecasted annual mean and April-July mean streamflows for Salmon Creek at Conconully Dam. Because of the paucity of model input data and uncertainty in the estimated unregulated streamflows, the model is not adequately calibrated and tested to estimate monthly mean streamflows for individual months, such as during low-flow periods, or for shorter periods such as during peak flows. In addition, no data were available to test the accuracy of simulated streamflows for lower Salmon Creek. Thus, although the simulated streamflows appear reasonable, the model should not be relied on to analyze historical and forecasted streamflows for Salmon Creek downstream of Conconully Dam (nodes 7 through 11; fig. 11). Instead, simulated streamflows for Salmon Creek at Conconully Dam should be considered a base estimate of streamflows that can be expected in lower Salmon Creek. The estimated 
streamflows may be reduced in reaches of lower Salmon Creek that are losing water and increased in reaches that are gaining water or that receive runoff from tributaries in lower Salmon Creek subbasin.

The two principal reasons for the less-than-optimal model calibration are as follows. First, historical records of precipitation and air-temperature data, particularly daily minimum and maximum air temperatures at high altitudes in upper Salmon Creek Basin, are limited. Second, the number of measurements for streamflow in Salmon Creek Basin is extremely limited and only an estimated time series of monthly mean runoff is available for upper Salmon Creek Basin. This estimated time series may contain several questionable values (Dames and Moore, 1999; U.S. Department of Energy, 2004; and this study). However, the estimated time series was used to calibrate and test the precipitation-runoff model because the time series represents the best available data for the basin. Errors in the precipitation and air-temperature model input time series and in the estimated streamflow data likely affected the accuracy of the calibrated model parameters.

The precipitation-runoff model described in this report is expected to be used for simulating historical streamflows and ESP forecasting of streamflows. ESP forecasting requires accurate simulation of initial hydrologic conditions on the basis of real-time precipitation and air-temperature data, and forecasting the probability of streamflows for as far as 1 year in the future by assuming that historical records of daily precipitation and air temperature will recur with the same probability as in the past. The historical record that can be used for ESP forecasts includes water years 1950-2004 (the COMPOSITE data set) and can be extended to the present by adding the most recent real-time precipitation and airtemperature data for the Conconully CCR Hydromet station and the most recent real-time air-temperature data for the Omak OMAW AgriMet station. The COMPOSITE data set includes both wet and dry years but does not include an extended, multiyear dry period known to have occurred in the Salmon Creek Basin from the late 1920s through the early 1930s. During that period, the record low annual mean runoff from upper Salmon Creek Basin was $2.1 \mathrm{ft}^{3} / \mathrm{s}$ (1,513 acreft) for water year 1931 (Dames and Moore, 1999; U.S. Department of Energy, 2004). The lowest annual mean runoff during water years $1950-2004$ is $6.1 \mathrm{ft}^{3} / \mathrm{s}(4,400$ acre- $\mathrm{ft})$ for water year 1966. The simulation of historical streamflows, initial hydrologic conditions, and the ESP forecast rely on the calibrated precipitation-runoff model described in this report and are subject to the model limitations discussed.

\section{Suggestions for Data Collection}

Starting in water year 1997 and continuing through at least water year 2003, data collection at the Conconully climate station stopped during the winter months, generally for November through February. As a result, the available records of overlapping measurements of daily precipitation and daily minimum and maximum air temperatures for the Conconully climate and Conconully CCR Hydromet stations is generally limited to non-winter months between August 1999 and the present (2006). If year-round data collection for the Conconully station were resumed, the resulting overlapping records would allow more thorough testing of the assumption made in this study that the daily precipitation and air temperatures measured for the Conconully CCR Hydromet station are equivalent to the daily precipitation and air temperatures measured for the Conconully station. Confirmation of this assumption is important because the use of the precipitation-runoff model developed in this study for ESP forecasts depends on real-time measurements for the Conconully CCR Hydromet station to be equivalent to the non-real-time measurements for the Conconully climate station.

Dames and Moore (1999) reported that starting in 1997 , releases from Conconully Reservoir were measured only through the outlet tunnel. This means that the measurements no longer include seepage below the dam and uncontrolled spills. It would be helpful if a stream gage were installed in Salmon Creek downstream of the spillway of Conconully Dam to measure all runoff from the upper Salmon Creek Basin.

Improved availability of climate and streamflow data for Salmon Creek Basin should enable improved calibration of the precipitation-runoff model described in this report. The improved model would increase the reliability of simulated historical streamflows and ESP forecasts of streamflows in the Salmon Creek Basin. This in turn would make the precipitation-runoff model a more reliable component of the DSS that Reclamation plans to use to study the water resources of the Salmon Creek Basin.

\section{Summary}

The U.S. Geological Survey (USGS), in cooperation with the Bureau of Reclamation (Reclamation), developed a precipitation-runoff model for the Salmon Creek Basin that can be used to simulate daily unregulated streamflows 
in the basin. The precipitation-runoff model is a component of a Decision Support System (DSS) that includes a wateroperations model Reclamation plans to develop to study the water resources of the Salmon Creek Basin. The DSS will be similar to the DSS that Reclamation and the USGS developed previously for the Yakima River Basin in central southern Washington. The precipitation-runoff model that was developed is a modified version of the PrecipitationRunoff Modeling System (PRMS; Leavesley and others, 1983) and was run within the Modular Modeling System (MMS; Leavesley and others, 1996). The model can be used to simulate historical streamflows and streamflows for as far as 1 year in the future using the Extended Streamflow Prediction (ESP) technique in MMS.

Model input time series were based on historical records of daily precipitation and daily minimum and maximum air temperatures for three National Weather Service stations, a Natural Resources Conservation Service SNOTEL station, a Bureau of Reclamation AgriMet station, and a Bureau of Reclamation Hydromet station. Model-calibration and testing time series were estimated records of monthly mean unregulated streamflow for Salmon Creek at Conconully Dam [referred to as uncorrected unregulated streamflow (UUS) in this study] based on reservoir outflows and storage changes (Dames and Moore,1999; U.S. Department of Energy, 2004; this study) and records of daily snowpack water-equivalent for the SNOTEL station. A second estimated time series of monthly mean unregulated streamflow for Salmon Creek at Conconully Dam was generated by adding estimates of groundwater losses and evaporative losses to the uncorrected time series [referred to as corrected unregulated streamflow (CUS) in this study]. The total of the corrections was about 9 percent of the long-term mean uncorrected unregulated streamflow. The time series of estimated monthly mean uncorrected unregulated streamflow has several potential sources of error (Dames and Moore, 1999; U.S. Department of Energy, 2004). However, the estimates were the best available and were used in this study as a surrogate for the missing long-term unregulated streamflows for Salmon Creek at Conconully Dam.

Salmon Creek Basin was subdivided into 179 Modeling Response Units (MRUs), each with similar physical, soil, and vegetation characteristics. Initial model parameters were assigned by applying the GIS (Geographic Information System) Weasel program (Viger and others, 1998), computing values from measured data, and using parameters from the Methow River precipitation-runoff model (Ely and Risley, 2001; Ely, 2003). The precipitation-runoff model was calibrated for water years 1950-89 (a water year starts October 1 and ends September 30) and tested for water years 1990-96. A subset of the initial model parameters was adjusted during the calibration process with the goal of simulating monthly unregulated streamflows for Salmon Creek at Conconully Dam that were more than the estimated UUS and less than the estimated CUS.

Model calibration and testing indicate that daily streamflows simulated using the precipitation-runoff model described in this report should be used only to analyze historical and forecasted annual mean and April-July mean streamflows for Salmon Creek at Conconully Dam. Because of the paucity of model input data and uncertainty in the estimated unregulated streamflows, the model is not adequately calibrated and tested to estimate monthly mean streamflows for individual months, such as during low-flow periods, or for shorter periods such as during peak flows.

For the calibration period, water years 1950-89, both the simulated mean annual streamflow and the simulated mean April-July streamflow compare well with the estimated values for UUS and CUS. The simulated mean annual streamflow exceeds UUS by 5.9 percent and is less than CUS by 2.7 percent. Similarly, the simulated mean April-July streamflow exceeds UUS by 1.8 percent and is less than CUS by 3.1 percent. A comparison of the estimated and simulated mean monthly streamflows, however, shows that streamflow is significantly undersimulated during the low-flow, baseflowdominated months of November through February when simulated monthly streamflows are as much as 57.2 percent less than UUS and significantly oversimulated during August and September when simulated monthly streamflows are as much as 193.6 percent more than CUS. During the low-flow months, however, estimated mean monthly streamflow is only a small percentage of the estimated mean annual streamflow and absolute errors are relatively small even though the percentages of error are large.

The precipitation-runoff model was tested for water years 1990-96 using model input time series for the same climate stations as for model calibration, except that measured temperatures were used for the AgriMet station instead of synthetic temperatures. The data set used for this testing is referred to as "TESTING 1." For TESTING 1, the model simulated a close fit for the mean annual streamflow and a good fit for the mean April-July streamflow. The simulated mean annual streamflow exceeds UUS by 10.7 percent and is the same as CUS. The simulated mean April-July streamflow exceeds UUS by 5.1 percent and is less than CUS by 0.8 percent. The precipitation-runoff model was tested three more times to determine if adding different combinations of daily precipitation for the real-time AgriMet and SNOTEL stations to the input time series for TESTING 1 
would improve the fit between estimated and simulated streamflows for water years 1990-96. For all three tests, the simulated mean annual and mean April-July streamflows were significantly larger than the estimated streamflows. The oversimulation was largest when precipitation for the AgriMet and SNOTEL stations was added (the simulated mean annual and mean April-July streamflows exceeded CUS by 20.7 percent and 21.3 percent, respectively) and smallest when precipitation for the Agrimet station was added (the simulated mean annual and mean April-July streamflows exceeded CUS by 6.0 percent and 5.3 percent, respectively). The testing results indicate that the precipitation-runoff model is adequately calibrated for the purpose of simulating annual mean and April-July mean streamflows using the input time series used for model calibration and testing. The addition of precipitation data for the AgriMet and/or SNOTEL stations to the input time series results in oversimulated annual mean and April-July mean streamflows.

A final comparison between estimated and simulated streamflows was made for the entire simulation period, water years 1950-2004. The input time series used for this simulation is referred to as "COMPOSITE" and is identical to the input time series for model calibration (water years 1950-89) and for TESTING 1 (water years 1990-96). For water years 1997-2004, the input time series consists of data for the same climate stations as CALIBRATION and TESTING 1, except that for water years 2000-04 daily precipitation and minimum and maximum air temperatures for one of the stations were replaced with data for the nearby realtime Hydromet station that were assumed to be equivalent. For COMPOSITE, the model simulated a good fit for the mean annual streamflow and a close fit for the mean April-July streamflow. The simulated mean annual streamflow exceeds UUS by 2.8 percent and is less than CUS by 5.7 percent. The simulated mean April-July streamflow is less than UUS by 0.7 percent and less than CUS by 5.6 percent. For forecasting purposes, Reclamation will expand the COMPOSITE data set to include the most recent real-time precipitation and airtemperature data for the Hydromet station and the most recent real-time air-temperature data for the AgriMet station.

During the driest 4 water years $(1964,1977,1979$, and 1985) and the wettest 4 water years (1951, 1971, 1982, and 1983) of the 40-year calibration period, the model simulated poor fits for the annual mean streamflows and April-July mean streamflows based on the percentages of errors with respect to UUS and CUS. However, during the driest 4 water years, the large percentages of error are with respect to relatively small streamflows for Salmon Creek at Conconully Dam. During the driest 4 water years, the absolute errors ranged from an undersimulation of annual mean streamflow with respect to UUS of $8.0 \mathrm{ft}^{3} / \mathrm{s}$ (46.8 percent error) in water year 1964 to an oversimulation of annual mean streamflow with respect to CUS of $3.4 \mathrm{ft}^{3} / \mathrm{s}$ (31.2 percent error) in water year 1985 . The absolute errors ranged from an undersimulation of April-July mean streamflow with respect to UUS of $13.6 \mathrm{ft}^{3} / \mathrm{s}$ (39.7 percent error) in water year 1964 to an oversimulation of April-July mean streamflow with respect to CUS of $4.2 \mathrm{ft}^{3} / \mathrm{s}$ (24.0 percent error) in water year 1985 . During the wettest 4 water years, the absolute errors ranged from an undersimulation of annual mean streamflow with respect to UUS of $2.8 \mathrm{ft}^{3} / \mathrm{s}$ ( 4.7 percent error) in water year 1951 to an oversimulation of annual mean streamflow with respect to CUS of $26.6 \mathrm{ft}^{3} / \mathrm{s}$ (73.1 percent error) in water year 1971. The absolute errors ranged from an undersimulation of April-July mean streamflow with respect to UUS of $19.8 \mathrm{ft}^{3} / \mathrm{s}$ (13.1 percent error) in water year 1951 to an oversimulation of April-July mean streamflow with respect to CUS of $74.1 \mathrm{ft}^{3} / \mathrm{s}$ (75.6 percent error) in water year 1971.

No data were available to test the accuracy of simulated streamflows for lower Salmon Creek. Thus, although the simulated streamflows appear reasonable, the model should not be relied on to analyze historical and forecasted streamflows for Salmon Creek downstream of Conconully Dam. Instead, simulated streamflows for Salmon Creek at Conconully Dam should be considered a base estimate of streamflows that can be expected in lower Salmon Creek. The estimated streamflows may be reduced in reaches of lower Salmon Creek that are losing water and increased in reaches that are gaining water or that receive runoff from tributaries in lower Salmon Creek subbasin.

The precipitation-runoff model described in this report is expected to be used for simulating historical streamflows and ESP forecasting of streamflows. ESP forecasting requires accurate simulation of initial hydrologic conditions on the basis of real-time precipitation and air-temperature data, and forecasting the probability of streamflows for as far as 1 year in the future by assuming that historical records of daily precipitation and air temperature will recur with the same probability as in the past. The historical record that can be used for ESP forecasts includes water years 1950-2004 and can be extended to the present by adding the most recent real-time data. The simulation of historical streamflows, initial hydrologic conditions, and the ESP forecast rely on the calibrated precipitation-runoff model described in this report and are subject to the model limitations that result from model error, data error, and parameter error.

The precipitation-runoff model described in this report could be improved in the future if additional data were collected. Specifically, it is suggested that yearround collection of climate data be resumed at Conconully station and that a stream gage be installed in Salmon Creek downstream of the spillway of Conconully Dam to measure all runoff from the upper Salmon Creek Basin. Improved availability of climate and streamflow data for the Salmon Creek Basin should enable improved calibration of the precipitation-runoff model, which would make the model a more reliable component of the DSS that Reclamation plans to use to study the water resources of the Salmon Creek Basin. 


\section{Acknowledgments}

The author thanks Tom Sullivan, Okanogan Irrigation District, for supplying measurements of monthly storage in Conconully and Salmon Lake Reservoirs and releases from Conconully Reservoir from January 2003 through March 2006. The author also thanks Mark C. Mastin and John J. Vaccaro, U.S. Geological Survey, for helpful discussions.

\section{References Cited}

Boyle, D.P., Fritchel, P.E., Lamorey, G., and Markstrom, S., 2004, Evaluation of a hydrologic model applied to a headwater basin in the Rio Grande (USA) using observed and modelled land surface fluxes and states, in PahlWostl, C., Schmidt, S., Rizzoli, A.E., and Jakeman, A.J., eds., Complexity and Integrated Resources Management, Transactions of the 2nd Biennial Meeting of the International Environmental Modelling and Software Society, iEMSs: Manno, Switzerland, 2004, ISBN 88900787-1-5.

Bureau of Reclamation, 2006a, AgriMet historical archive weather data access: accessed April 30, 2006, at http:// www.usbr.gov/pn/agrimet/webarcread.html

Bureau of Reclamation, 2006b, Description of Okanogan Project: accessed May 23, 2006, at http://www.usbr.gov/ dataweb/html/okanogan.html

Bureau of Reclamation, 2006c, Hydromet historical data access: accessed September 7, 2006, at http://www.usbr. gov/pn/hydromet/arcread.html

Bureau of Reclamation and Center for Advanced Decision Support for Water and Environmental Systems (CADSWES), 2000, RiverWare; accessed May 26, 2006, Fact Sheet at http://www.usbr.gov/pmts/rivers/warsmp/ riverware/index.html

Cassidy, K.M., 1997, Land cover of Washington State: Description and management, Gap Analysis of Washington State-Final Report, v. 1: Washington Cooperative Fish and Wildlife Research Unit, University of Washington, 260 p.

Daly, C., Gibson, W.P., Taylor, G.H., Johnson, G.L., and Pasteris, P., 2002, A knowledge-based approach to the statistical mapping of climate: Climate Research, v. 22, p. 99-113.

Daly, C., and Johnson, G.L., 1999, PRISM spatial climate layers - their development and use: Short Course on Topics in Applied Climatology, 79th Annual Meeting of the American Meteorological Society, January 10-15, Dallas, Texas, $49 \mathrm{p}$.
Daly, C., Neilson, R.P., and Phillips, D.L., 1994, A statisticaltopographic model for mapping climatological precipitation over mountainous terrain: Journal of Applied Meteorology, v. 33 , p. $140-158$.

Dames and Moore, 1999, Joint study on Salmon Creek-final report prepared for Colville Confederated Tribes and Okanogan Irrigation District, [about 250] p.

Day, G.N., 1985, Extended streamflow forecasting using NWSRFS: Journal of Water Resources Planning and Management, ASCE, v. 111, no. 2, p. 157-170.

Ely, D.M., 2003, Precipitation-runoff simulations of current and natural streamflow conditions in the Methow River Basin, Washington: U.S. Geological Survey WaterResources Investigations Report 03-4246, 35 p.

Ely, D.M., and Risley, J.C., 2001, Use of a precipitation-runoff model to simulate natural streamflow conditions in the Methow River Basin, Washington: U.S. Geological Survey Water-Resources Investigations Report 01-4198, 36 p.

Farnsworth, R.K., Thompson, E.S., and Peck, E.L., 1982, Evaporation atlas for the contiguous 48 United States: NOAA Technical Report NWS 33, Washington, D.C., 4 plates, 26 p.

Fetter, C.W., 1994, Applied hydrogeology (3d ed.): Upper Saddle River, N.J., Prentice Hall, 691 p.

Hydrosphere Data Products, 2005, CD-ROM National Climatic Data Center summary of the day - west 2, v. 16.3.

Jensen, M.E., and Haise, H.R., 1963, Estimating evapotranspiration from solar radiation: Proceedings of the American Society of Civil Engineers, Journal of Irrigation and Drainage, v. 89, no. IR4, p. 15-41.

Jeton, A.E., 1999, Precipitation-runoff simulations for the upper part of the Truckee River Basin, California and Nevada: U.S. Geological Survey Water-Resources Investigations Report 99-4282, 41 p.

Kahle, S.C., 1998, Hydrogeology of Naval Submarine Base Bangor and vicinity, Kitsap County, Washington: U.S. Geological Survey Water-Resources Investigations Report 97-4060, 107 p.

Kahle, S.C., Longpré, C.I., Smith, R.R., Sumioka, S.S., Watkins, A.M., and Kresch, D.L., 2003, Water resources in the ground-water system in unconsolidated deposits of the Colville River watershed, Stevens County, Washington: U.S. Geological Survey Water-Resources Investigations Report 03-4128, 76 p. 
Kuhn, G., Parker, R.S., Hay, L.E., and Leavesley, G.H., 1998, Precipitation distribution alternatives in applying the Modular Modeling System in the San Juan River Basin, Colorado and New Mexico, in Proceedings of the First Federal Interagency Hydrologic Modeling Conference, April 19-23, 1998: Las Vegas, Nevada, Interagency Advisory Committee on Water Data, v. 2, chap. 5, p. 85-92.

Laenen, A., and Risley, J.C., 1997, Precipitation-runoff and streamflow-routing models for the Willamette River Basin, Oregon: U.S. Geological Survey Water-Resources Investigations Report 95-4284, 197 p.

Leavesley, G.H., Lichty, R.W., Troutman, B.M., and Saindon, L.G., 1983, Precipitation-runoff modeling system-User's manual: U.S. Geological Survey Water-Resources Investigations Report 83-4238, 207 p.

Leavesley, G.H., Restrepo, P.J., Markstrom, S.L., Dixon, M., and Stannard, L.G., 1996, The modular modeling system (MMS)_User's manual: U.S. Geological Survey Open-File Report 96-151, 200 p.

Mastin, M.C., and Vaccaro, J.J., 2002a, Documentation of precipitation runoff modeling system modules for the Modular Modeling System modified for the Watershed and River Systems Management Program: U.S. Geological Survey Open-File Report 02-362, 5 p.

Mastin, M.C., and Vaccaro, J.J., 2002b, Watershed models for decision support in the Yakima River Basin, Washington: U.S. Geological Survey Open-File Report 02-404, 46 p.

Powell, D.S., Faulkner, J.L., Darr, D.R., Zhu, Z., and MacCleery, D.W., 1993, Forest resources of the United States, 1992: U.S. Forest Service General Technical Report RM-234, Rocky Mountain Forest and Range Experiment Station, Fort Collins, Colo., 132 p.

Risley, J.C., 1994, Use of a precipitation-runoff model for simulating effects of forest management on streamflow in 11 small drainage basins, Oregon Coast Range: U.S. Geological Survey Water-Resources Investigations Report 93-4181, 61 p.

Schuster, J.E., 2005, Geologic map of Washington State: Washington Division of Geology and Earth Resources Geologic Map GM-53, 44 p., 1 plate.

Stoffel, K.L., compiler, 1990, Geologic map of the Oroville 1:100,000 quadrangle, Washington: Washington Division of Geology and Earth Resources Open File Report 90-11, 58 p., 1 plate.

Spatial Climate Analysis Service-Oregon State University, 2006: accessed January 19, 2006, at http://www.ocs.orst. edu/prism/
U.S. Census Bureau, 2006: accessed May 23, 2006, at http:// www.ofm.wa.gov/census2000/profiles/place/1605314310. pdf

U.S. Department of Agriculture, 1994, State Soil Geographic (STATSGO) Database-Data use information: Fort Worth Texas, U.S. Soil Conservation Service, National Cartography and GIS Center.

U.S. Department of Agriculture, 2006, Natural Resources Conservation Service, Historic data - daily SNOTEL data: accessed April 30, 2006, at http://www.wa.nrcs.usda. gov/snow/data/historic.html

U.S. Department of Energy, 2004, Salmon Creek ProjectDraft Environmental Impact Statement DOE/EIS-0346: [about 800] p.

U.S. Geological Survey, 1992, 1990 conterminous U.S. land cover characteristics data set CD-ROM: Sioux Falls, South Dakota, EROS Data Center, National Mapping Division.

U.S. Geological Survey, 1998, Watershed and river systems management program-Application to the Yakima River Basin, Washington: U.S. Geological Survey Fact Sheet FS-037-98, 4 p.

U.S. Geological Survey and Bureau of Reclamation, 2006, Watershed and River Systems Management System: accessed May 26, 2006, at http://wwwbrr.cr.usgs.gov/ warsmp

Viger, R.J., Markstrom, S.L., and Leavesley, G.H., 1998, The GIS Weasel-An interface for the treatment of spatial information used in watershed modeling and water resource management, in Proceedings of First Federal Interagency Hydrologic Modeling Conference, April 19-23, 1998: Las Vegas, Nevada, Interagency Advisory Committee on Water Data, v. 2, chap. 7, p. 73-80.

Vogelmann, J.E., Howard, S.M., Yang, L., Larson, C.R., Wylie, B.K., and Van Driel, N., 2001, Completion of the 1990s national land cover data set for the conterminous United States from Lansat thematic mapper data and ancillary data sources: Photogrammetric Engineering and Remote Sensing, v. 67, p. 650-652.

Washington State Department of Ecology, 2006a, River and stream flow monitoring: accessed September 24, 2006 at https://fortress.wa.gov/ecy/wrx/wrx/flows/station. asp?sta $=49 \mathrm{M} 100$

Washington State Department of Ecology, 2006b, Well logs: accessed May 2006 at http://apps.ecy.wa.gov/welllog

Zhu, Z., and Evans, L.D., 1992, Mapping midsouth forest distributions: Journal of Forestry, v. 90, no. 12, p. 27-30. 
Appendix 1. Monthly Values of Total Water in Storage in Conconully and Salmon Lake Reservoirs, Releases from Conconully Reservoir, and Computed Unregulated Precipitation Runoff From Upper Salmon Creek Basin, January 2003-March 2006

\begin{tabular}{|c|c|c|c|c|}
\hline Year & Month & $\begin{array}{c}\text { Total water in storage in } \\
\text { Conconully and Salmon Lake } \\
\text { Reservoirs at the end of the } \\
\text { month } \\
\text { (acre-feet) }\end{array}$ & $\begin{array}{l}\text { Releases from } \\
\text { Conconully } \\
\text { Reservoir }{ }^{1} \\
\text { (acre-feet) }\end{array}$ & $\begin{array}{l}\text { Computed unregulated } \\
\text { watershed runoff from upper } \\
\text { Salmon Creek Basin } \\
\text { (acre-feet) }\end{array}$ \\
\hline 2002 & 12 & 6,108 & & \\
\hline 2003 & 1 & 6,476 & 0 & 368 \\
\hline 2003 & 2 & 6,837 & 0 & 361 \\
\hline 2003 & 3 & 7,350 & 216 & 729 \\
\hline 2003 & 4 & 9,404 & 1,080 & 3,134 \\
\hline 2003 & 5 & 12,845 & 1,475 & 4,916 \\
\hline 2003 & 6 & 15,642 & 2,060 & 4,857 \\
\hline 2003 & 7 & 13,321 & 2,540 & 219 \\
\hline 2003 & 8 & 10,482 & 2,590 & -249 \\
\hline 2003 & 9 & 8,532 & 1,840 & -110 \\
\hline 2003 & 10 & 9,008 & 0 & 476 \\
\hline 2003 & 11 & 9,354 & 0 & 346 \\
\hline 2003 & 12 & 9,778 & 0 & 424 \\
\hline 2004 & 1 & 10,156 & 0 & 378 \\
\hline 2004 & 2 & 10,442 & 0 & 286 \\
\hline 2004 & 3 & 10,738 & 0 & 296 \\
\hline 2004 & 4 & 12,530 & 255 & 2,047 \\
\hline 2004 & 5 & 14,103 & 1,945 & 3,518 \\
\hline 2004 & 6 & 14,072 & 2,030 & 1,999 \\
\hline 2004 & 7 & 12,602 & 2,400 & 930 \\
\hline 2004 & 8 & 10,859 & 2,310 & 567 \\
\hline 2004 & 9 & 9,033 & 1,810 & -16 \\
\hline 2004 & 10 & 9,601 & 0 & 568 \\
\hline 2004 & 11 & 10,029 & 0 & 428 \\
\hline 2004 & 12 & 10,474 & 0 & 445 \\
\hline 2005 & 1 & 10,900 & 0 & 426 \\
\hline 2005 & 2 & 11,149 & 0 & 249 \\
\hline 2005 & 3 & 11,659 & 66 & 576 \\
\hline 2005 & 4 & 12,632 & 140 & 1,113 \\
\hline 2005 & 5 & 14,941 & 1,480 & 3,789 \\
\hline 2005 & 6 & 15,684 & 1,850 & 2,593 \\
\hline 2005 & 7 & 13,816 & 2,490 & 622 \\
\hline 2005 & 8 & 11,154 & 2,370 & -292 \\
\hline 2005 & 9 & 9,480 & 1,710 & 36 \\
\hline 2005 & 10 & 10,106 & 180 & 806 \\
\hline 2005 & 11 & 10,646 & 0 & 540 \\
\hline 2005 & 12 & 11,065 & 0 & 419 \\
\hline 2006 & 1 & 11,553 & 0 & 488 \\
\hline 2006 & 2 & 12,018 & 0 & 465 \\
\hline 2006 & 3 & 12,559 & 0 & 541 \\
\hline
\end{tabular}

${ }^{1}$ Data from T. Sullivan, Okanogan Irrigation District, written commun., 2006. 
This page intentionally left blank. 
Manuscript approved for publication, October 17, 2006

Prepared by the USGS Publishing Network,

Publishing Service Center, Tacoma, Washington

Bob Crist

Bill Gibbs

Debra Grillo

Bobbie Jo Richey

Sharon L. Wahlstrom

Publishing Service Center, Bismark, North Dakota Cathy R. Martin

For more information concerning the research in this report, contact the Director, Washington Water Science Center

U.S. Geological Survey, 934 Broadway - Suite 300

Tacoma, Washington 98402

http://wa.water.usgs.gov 
